\title{
Vegetation and climate in the Miocene deposits of southern side of the Büyük Menderes Graben, Şahinali-2 core, SW Turkey
}

\author{
MEHMET SERKAN AKKIRAZ
}

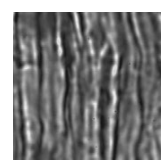

\begin{abstract}
Lower-Middle Miocene succession from the Șahinali coalfield (SW Turkey) was analyzed to reconstruct climate and vegetation. The sediments mainly represent a lacustrine facies and consist of a mudstone-marl dominated succession, including limited coarse-grained clastics. Results of microfloral and published macrofloral records have been considered. The main vegetation types were mixed mesophytic forest dominated by evergreen Quercus and coniferous forest consisting mainly of indeterminate Pinaceae, Pinus and Cupressaceae. In this belt riparian vegetation incorporates high proportions of Alnus, and less amounts of deciduous Salix, Ulmus, Pterocarya, Carya, Platanus, Zelkova and Liquidambar. Herbaceous components in the pollen spectra are in low frequencies, and consist of Poaceae, Brassicaceae, Chenopodiaceae, Ephedra, Asteraceae and Caryophyllaceae. Also three local pollen zones can be recognized based on the changes in relative abundances of palynomorphs. The micro- and published macrofloral records have been subjected to the Coexistence Approach method to obtain the palaeoclimate. Mean annual temperature is estimated to be over $14{ }^{\circ} \mathrm{C}$ and mean annual precipitation exceeds $1000 \mathrm{~mm}$. In combination with other climate parameters (temperatures of warmest and coldest months, precipitation of the wettest, driest and warmest months), the data indicate very stable warm-temperate with high annual precipitation. Results of the Coexistence Approach using both sporomorph and leaf datasets are good in agreement, implying internal consistency in the method. Compared with modern meteorological records, surroundings of the Büyük Menderes Graben had similar temperature and higher precipitation during the Early-Middle Miocene. This study contributes to an understanding of the Miocene vegetation and climate evolution in southeastern Mediterranean area. - Keywords: Early-Middle Miocene, Büyük Menderes Graben, Southeastern Mediterranean, palynology, palaeoclimate.
\end{abstract}

AKKIRAZ, M.S. 2011. Vegetation and climate in the Miocene deposits of southern side of the Büyük Menderes Graben, Șahinali-2 core, SW Turkey. Bulletin of Geosciences 86(4), 859-878 (9 figures, 3 tables). Czech Geological Survey, Prague. ISSN 1214-1119. Manuscript received March 18, 2011; accepted in revised form June 13, 2011; published online July 26, 2011; issued November 16, 2011.

Mehmet Serkan Akkiraz, Dumlupinar University, Department of Geological Engineering, Main Campus, 43270, Kütahya,Turkey;sakkiraz73@gmail.com,serkanakkiraz@dpu.edu.tr

Miocene lignite bearing-continental deposits from the western part of Turkey (southeastern Mediterranean Zone) are well known for their economic potential [e.g., ManisaSoma; Kütahya (Seyitömer and Tunçbilek); Çanakkale-Çan basins]; see Fig. 1A. A number of studies dealing with Cenozoic palynology and palaeobotany have been carried out in these areas (e.g., Becker-Platen 1970; Benda 1971; Benda \& Meulenkamp 1979, 1990; Mädler \& Steffens 1979; Ediger 1990; Ediger et al. 1990; Akgün \& Akyol 1999; Akgün et al. 2007; Yavuz-Ișik 2007, 2008; Erdei et al. 2010; Akkiraz et al. 2011). The first palynological studies were made to solve the stratigraphy by means of form-generic names for most of pollen and spores (Akyol 1964, 1968; Nakoman 1965; Benda 1971; Benda \& Meulenkamp 1979, 1990; Akgün \& Akyol 1999). Recently, statistical methods have been applied to pollen samples in order to obtain reliable information about floral diversity, vegetation and climate (Akgün et al. 2007; Yavuz-Ișık 2007, 2008; Kayseri \& Akgün 2008; Akkiraz et al. 2011).

The most comprehensive published work on micro- and macrofloras of the Şahinali open cast mine (southern side of the Büyük Menderes Graben) was carried out by Gemici et al. (1993) who suggested Middle Miocene age (Fig. 1A, B). This age was palynologically confirmed by Akgün \& Akyol (1999) as well. Palynoflora of Aydın-İncirliova, Köșk, Başçayır, Sarayköy and Hasköy areas in the northern part and those of in Aydın-Söke, Șahinali and Kuloğulları areas in the southern side of the Büyük Menderes Graben were investigated by Akgün \& Akyol (1999) who suggested Early-Middle Miocene. Moreover, well preserved leaf flora from the Sahinali open cast mine was determined from the muddy sediments, and assigned to Serravallian by Mädler \& Steffens (1979). Miocene sediments of the Söke Basin 


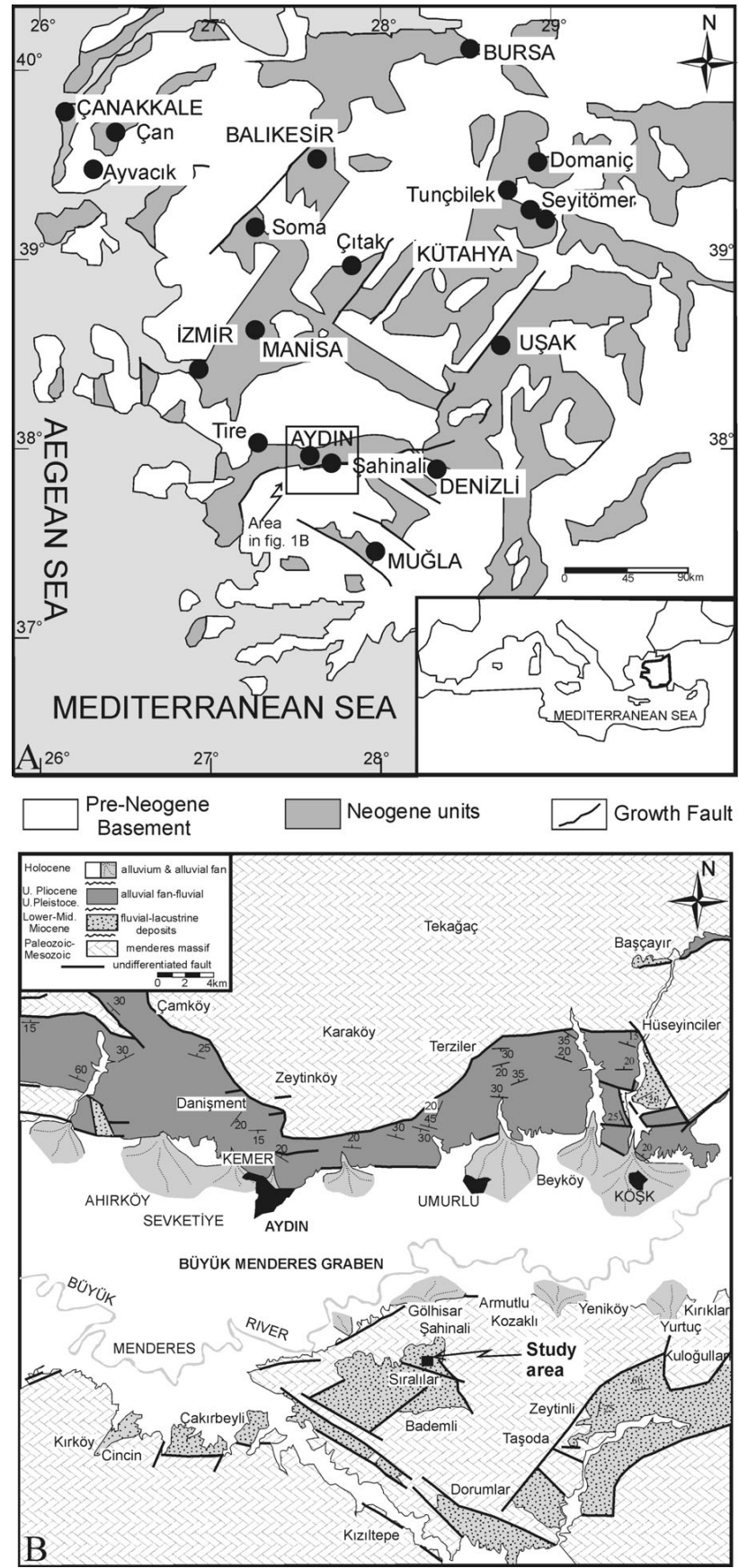

Figure 1. Map showing the lignite-bearing locations in western Turkey (A) and location of the studied Șahinali-2 core in the Șahinali open cast mine (B) (modified from Görür et al. 2009).

(Söke Formation) located about $70 \mathrm{~km}$ west of the current study area have similar lithologies to the Șahinali open cast mine and were dated as Early-Middle Miocene on the basis of mammal zone (MN4-6) (Gürer et al. (2009). Ünay \& Göktaș (1999) described a well-preserved mammal fauna from the Söke and Dededağ Formations. The following fossil assemblages were determined from the Söke Formation indicating the Orleanian (late Early Miocene - MN-4) age:
Cricetodon cf. tobieni, Democricetodon n. sp., Megacricetodon cf. primitivus, Lartetomys sp., Spanocricetodon sp., Anomalomys sp., Glirulus sp., Debruijina n. sp., Albertona aegeensis n. sp., Schizogalerix sp. from the Söke locality, and Cricetodon n. sp., Megacricetodon primitivus, Anomalomys aliveriensis, ?Vasseuromys sp., Debruijnia sp., Schizogalerix sp. from the Dededağ locality. Alçiçek (2010) studied the regional palaeogeography, stratigraphy and tectonism of the Neogene units in southwestern part of Turkey, and suggested middle Burdigalian-early Serravallian (Early-Middle Miocene) for the Söke Formation on the basis of mammal fauna studied by Becker-Platen (1970) and Gürer et al. (2009). Unfortunately, the age of lignite-bearing sediments in the northern and southern sides of the Büyük Menderes Graben is still a matter of debate and more precise dating is needed. Additionally, despite the fact that exploration and exploitation have been going on in the Șahinali open cast mine since 1960s, relatively limited information have been obtained on the flora, vegetation and palaeoclimate.

In this study the knowledge on the pollen flora has been enlarged by analysis of new samples from the Lower-Middle Miocene sequence of the Șahinali open cast mine. Also, the vegetation and palaeoclimate have been reconstructed independently by quantitative methods. Sediments of the present core represent a continuous stratigraphic sequence available for pollen studies in the Miocene of SW Turkey.

\section{Studied area}

\section{Modern climate and vegetation}

The Șahinali open cast mine located around $255 \mathrm{~m}$ a.s.l. lies between the Büyük Menderes Graben on the north and hills with elevations of 400-600 $\mathrm{m}$ a.s.l. on the south. Climate of the area is under influences of Mediterranean type. It is hot and dry in summers and warm and rainy in winters with an annual rainfall between 400 and $1000 \mathrm{~mm}$ (Kadığlu 2000) (Table 1).

The modern vegetation belongs to the region of Mediterranean pines, covered with Pinus brutia, P. nigra, $P$. halepensis. Mediterranean woodland (including xeric variety) consists of Quercus ilex, $Q$. coccifera, Pistascia lentiscus, Olea europaea var. oleaster, Ceratonia siliqua, Nerium oleander, Ulmus glabra, Juniperus, Poaceae and other herbs (Roberts \& Wright 1993).

\section{Geological setting and lithology of the Şahinali coalfield}

During the Miocene western Turkey displayed a long-term trend of decreasing marine influence. Alpine tectonics 


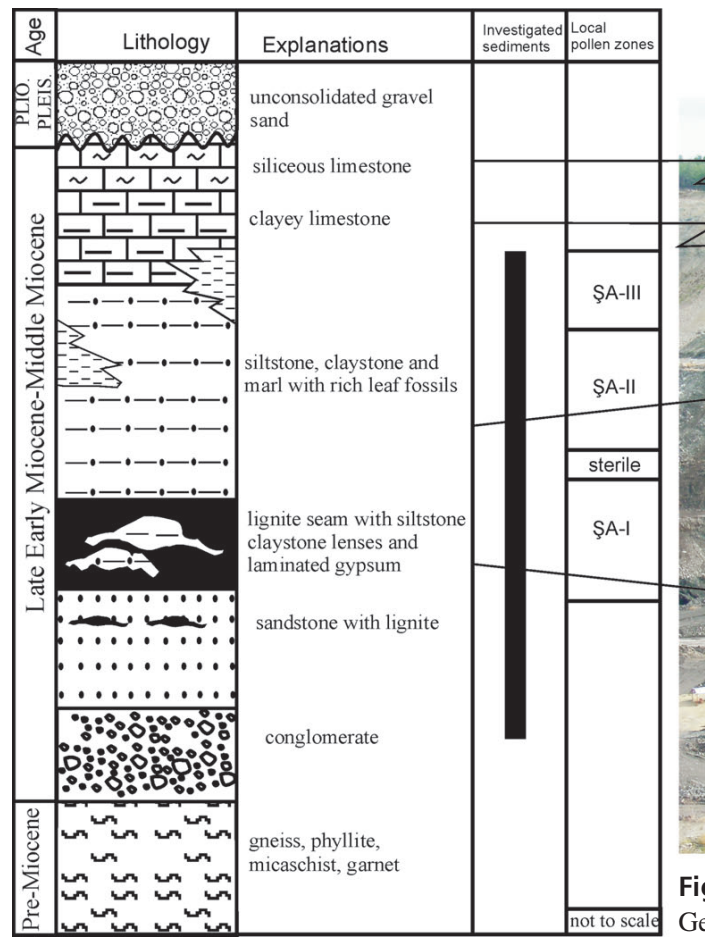

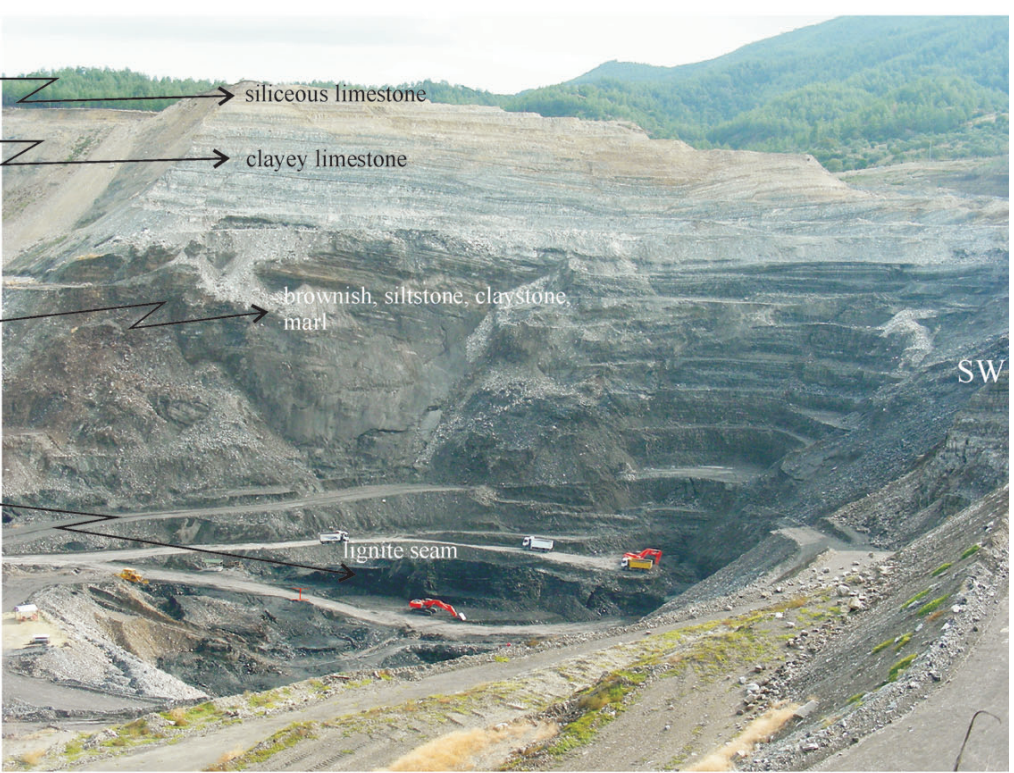

Figure 2. Șahinali open cast mine showing the position of the sequence (modified from Gemici et al. 1993).

Table 1. Climatic parameters of Early-Middle Miocene in the Șahinali open cast mine obtained by the CA compared with the modern ones (MAT: mean annual temperature, CMT: mean temperature of the coldest month, WMT: mean temperature of warmest month, MAP: mean annual precipitation, HMP: precipitation of the wettest month; LMP: precipitation of the direst month; WMP: precipitation of the warmest month).

\begin{tabular}{|c|c|c|c|}
\hline \multirow[t]{2}{*}{ Climate parameters } & \multicolumn{2}{|c|}{ Early-Middle Miocene (Șahinali open cast mine) } & \multirow[t]{2}{*}{ Modern } \\
\hline & Leaf flora & Palynoflora & \\
\hline $\operatorname{MAT}\left({ }^{\circ} \mathrm{C}\right)$ & $\begin{array}{c}14.4-15.4{ }^{\circ} \mathrm{C} \\
\text { Quercus incana - Castanopsis chrysoph }\end{array}$ & $\begin{array}{c}15.6-18.4^{\circ} \mathrm{C} \\
\text { Engelhardia-Cedrus }\end{array}$ & $14-18^{\circ} \mathrm{C}$ \\
\hline $\mathrm{CMT}\left({ }^{\circ} \mathrm{C}\right)$ & $\begin{array}{c}5.6-7.0^{\circ} \mathrm{C} \\
\text { Laurus and Fagus orientalis }\end{array}$ & $\begin{array}{c}7.7-12.5^{\circ} \mathrm{C} \\
\text { Engelhardia-Cedrus }\end{array}$ & $7-8^{\circ} \mathrm{C}$ \\
\hline WMT $\left({ }^{\circ} \mathrm{C}\right)$ & $\begin{array}{c}26.4-27.7^{\circ} \mathrm{C} \\
\text { Sapindus - Populus balsamifera }\end{array}$ & $\begin{array}{c}24.7-28.1^{\circ} \mathrm{C} \\
\text { Engelhardia }- \text { Cupressaceae }\end{array}$ & $27-29^{\circ} \mathrm{C}$ \\
\hline MAP (mm) & $\begin{array}{c}1031-1171 \mathrm{~mm} \\
\text { Myrica cerifera - Castanopsis chrysoph }\end{array}$ & $\begin{array}{c}1003-1520 \mathrm{~mm} \\
\text { Arecoideae - Taxodiaceae }\end{array}$ & $400-1000 \mathrm{~mm}$ \\
\hline $\operatorname{HMP}(\mathrm{mm})$ & $\begin{array}{c}\text { 124-134 mm Myrica cerifera-Populus } \\
\text { balsamifera }\end{array}$ & $\begin{array}{c}204-227 \mathrm{~mm} \\
\text { Engelhardia - Pinus diploxylon type }\end{array}$ & $150-450 \mathrm{~mm}$ \\
\hline LMP (mm) & $\begin{array}{c}10-11 \mathrm{~mm} \\
\text { Populus balsamifera }- \text { Castanopsis chrysoph }\end{array}$ & $\begin{array}{c}16-41 \mathrm{~mm} \\
\text { Podocarpaceae -Cedrus }\end{array}$ & $0-20 \mathrm{~mm}$ \\
\hline WMP (mm) & $\begin{array}{c}90-94 \mathrm{~mm} \\
\text { Myrica cerifera }- \text { Populus balsamifera }\end{array}$ & $\begin{array}{c}79-125 \mathrm{~mm} \\
\text { Engelhardia - Pinus diploxylon type }\end{array}$ & $100-200 \mathrm{~mm}$ \\
\hline
\end{tabular}

were active during the Late Cretaceous and Early Cenozoic periods (Collins \& Robertson 2003, Robertson et al. 2003), producing uplift of the Taurides. The convergence between the Africa and Eurasian plates led to the development of two distinct realms during the Miocene and Pliocene: The Mediterranean and Paratethys seas (Rögl 1998, Meulenkamp \& Sissing 2003). Then lacustrine sediments were filled in most of the Miocene basins in western Turkey. Succession of the Büyük Menderes Graben is made up of Miocene-Quaternary terrestrial sediments. Numerous studies concerning the stratigraphy, sedimentology and tectonism were carried out in the graben (Șengör et al. 1985; Șengör 1987; Seyitoğlu \& Scott 1991, 1992; Ünay et al. 1995; Emre \& Sözbilir 1997; Akgün \& Akyol 1999; Y1lmaz et al. 2000; Gürer et al. 2001, 2009; Seyitoğlu et al. 2004; Koçyiğit 2005; Bozkurt \& Mittwede 2005; Kaymakçı 2006; Alçiçek 2010).

The Șahinali coalfield $\left(37^{\circ} 46^{\prime} 12^{\prime \prime} \mathrm{N}, 27^{\circ} 55^{\prime} 48^{\prime \prime} \mathrm{E}\right.$ and $255 \mathrm{~m}$ alt.) is situated around $15 \mathrm{~km}$ southern part of the Büyük Menderes Graben, southeast of Aydin (Fig. 1A, B). 


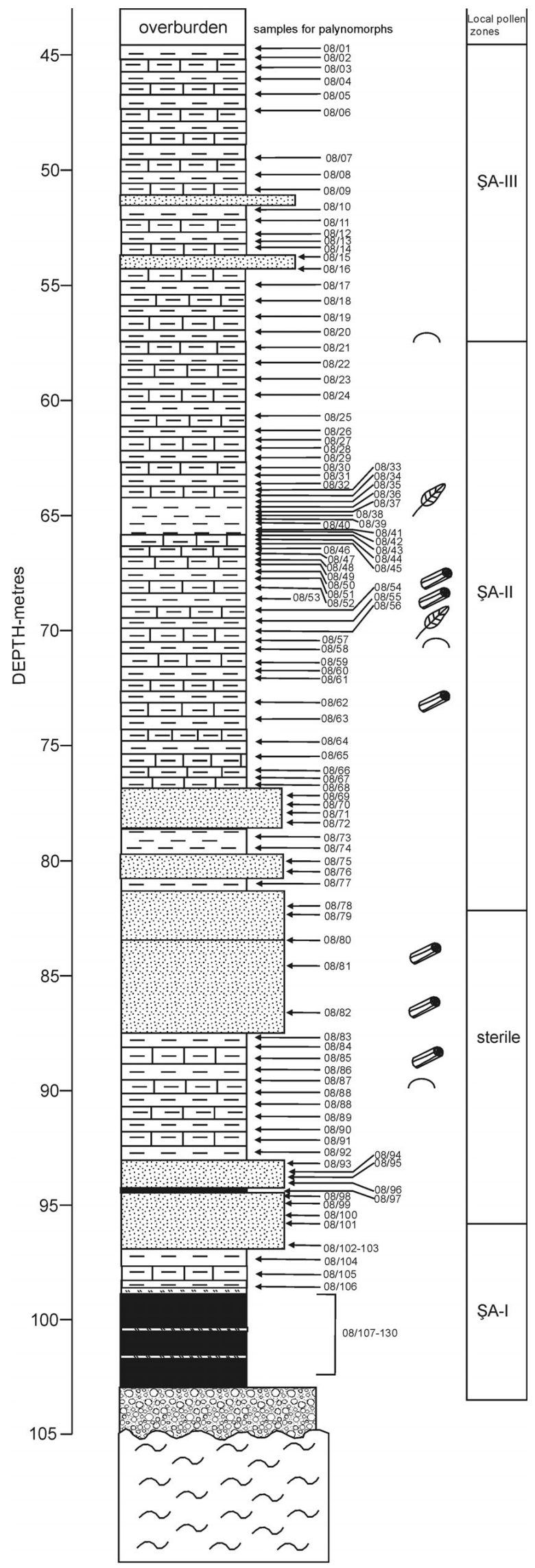

The Lower-Middle Miocene units were deposited in approximately $9 \mathrm{~km}$ length and $9 \mathrm{~km}$ width covering an area of over $81 \mathrm{~km}^{2}$ extending in a NE-SW direction (Fig. 1B) and rest unconformably on crystalline schists and gneiss of the Menderes Massif (Bozkurt 1999, Bozkurt \& Satır 2000, Bozkurt \& Oberhändsli 2001, Koralay et al. 2004) (Fig. 2). According to the field observations and estimations, sediments were not subjected to a strong tectonism since dip and strike of bedding plane is almost horizontal (Fig. 3). Small-scale foldings and normal faults occurred in the sequence. Apart from conglomerates and sandstones at the base, the units appear relative uniform and homogeneous, and consist of fine-grained deposits, mudrock and marl alternation (Figs 2,3). The most common components of the conglomerates include grains of the crystalline schist, gneiss and abundantly quartz derived from the basement. These coarse-grained clastics grade into sandstones which were covered by a lignite seam with $7-8 \mathrm{~m}$ on average thickness (Figs 2, 3). Thin to medium bedded gypsum levels occur both within the lignite seam and upper side of the lignite level. Gypsum levels may be weathering products of sulphide and carbonate minerals (Vassilev \& Vassileva 1996) and may indicate that the sulphate content in waters was probably increased as a consequence of evaporation under dry conditions. Gypsum-bearing lignites then evolved into an alkaline lake since the sequence continued upward with sandstones, claystones and marl alternation, reaching to $100 \mathrm{~m}$ total thickness (Fig. 3). Marl dominated lithologies contain plant debris, leaves and ostracods (Fig. 3). The Miocene units end with clayey and siliceous limestones (Fig. 2) and are unconformably overlain by the Pliocene-Pleistocene unconsolidated coarse-grained sediments (Fig. 2).

\section{Published flora}

In addition to the palynoflora from the Șahinali coalfield, leaf flora from the same area has been evaluated. The well-preserved leaf fossils described by Mädler \& Steffens (1979) and Gemici et al. (1993) were taken from the marl dominated lithologies above the main coal seam (Figs 2, 3).

Figure 3. Figure shows the depths at which samples were taken from the core.

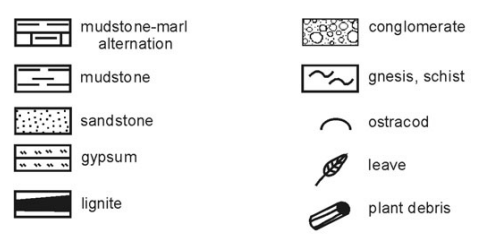




\section{Material and methods}

\section{Material}

The Șahinali-2 core is located at the northeast of the coalfield (Fig. 1B) was drilled to a total depth of 105 metres by Aydın Lignite Company until they reached to the basement (Fig. 3). A total of 130 samples were collected for palynological purposes, at an average distance of $45 \mathrm{~cm}$. But quantitative data are confined to 55 productive samples. No palynomorphs were found in 75 samples (e.g., 08/03, 08/04, 08/42), possibly owing to environmental conditions inappropriate for pollen preservation (Fig. 3). Since samples between 08/121 and 08/125 included low amounts of spore and pollen, these samples were combined to sample (Figs 4, 6). Therefore, 51 samples were suitable for palynological counting (Fig. 4).

\section{Preparation methods}

For palynological studies, ten grams of each sample were treated with HCL-HF-Acetolysis according to standard procedures. The organic residue was sieved through an $8 \mu \mathrm{m}$ mesh screen and 1-3 slides per sample of the $>8 \mu \mathrm{m}$ fraction were prepared for transmitted light microscopy. Pollen counts were carried out at a magnification of $400 \times$ using an Olympus microscope. Sporomorph contents of the samples are shown in a detailed palynological analytical diagram (Fig. 4). In this study, freshwater algae Botryococcus were not considered from the total sum used for calculating spore and pollen percentages, with a minimum of 200 grains of pollen and spores counted for all samples. In addition, a synthetic pollen diagram was plotted (Suc 1984, Jiménez-Moreno et al. 2005), in which pollen taxa have been arranged in 10 groups based on the ecological criteria (Fig. 5). Selected sporomorphs were photographed by the help of an Olympus BX51 microscope and Dewinter Caliper Pro 4.1 camera (Figs 7-9). TILIA software was used for calculating the pollen and spore records, and TILIAGRAPH was used for plotting the pollen diagram (Grimm 1994).

\section{Method of palaeoclimate reconstruction}

Palaeoclimate proxies are made on the basis of the Coexistence Approach (CA) (Mosbrugger \& Utescher 1997), a computer-aided for quantitative terrestrial climate reconstructions during the Paleogene and the Neogene using plant fossils. According to this technique the climatic requirements of the fossil plant taxa are similar to those of their Nearest Living Relatives (NLRs). The resolution rises with the number of the taxa included in the
Table 2. Macrofloral list of Șahinali open cast mine with Nearest Living Relatives of the fossil taxa.

\begin{tabular}{|c|c|}
\hline Fossil taxa & $\begin{array}{l}\text { Nearest Living Relatives; } \\
\text { bold: taxa reponsible for } \\
\text { climate intervals }\end{array}$ \\
\hline $\begin{array}{l}\text { Alnus phocaeensis Sap. }(=\text { cf. nepalensis } \\
\text { Don) }\end{array}$ & Alnus sp. \\
\hline Acer sp. & Acer sp. \\
\hline Betula subpubescens Goepp. & Betula pubescens \\
\hline Carya serraefolia (Goepp.) Krä. & Carya cordiformis \\
\hline cf. Castanea kubinyi Kov. & Castanea sp. \\
\hline Castanopsis sp. & Castanopsis chrysoph \\
\hline Cercis antiqua Sap. & Cercis sp. \\
\hline $\begin{array}{l}\text { Cinnamomophyllum scheuchzeri (Heer) } \\
\text { Kr. \& Weyl. }\end{array}$ & Lauraceae \\
\hline Daphnogene polymorpha (A. Br.) Ettin. & Daphnogene sp. \\
\hline Diospyros cf. anceps & Diospyros sp. \\
\hline Diospyros sp. & Diospyros sp. \\
\hline Fagus orientalis Lip. & Fagus orientalis \\
\hline Fagus attenuata Goepp. & Fagus ferruginea \\
\hline Fraxinus sp. & Fraxinus sp. \\
\hline Glumophyllum sp. & Monocotyledoneae \\
\hline Glyptostrobus europaeus (Brongn.) Heer & Glyptostrobus pensilis \\
\hline $\begin{array}{l}\text { Laurophyllum primigenium (Ung.) Kr. \& } \\
\text { Weyl. in Mad. \& Steff. }\end{array}$ & Lauraceae \\
\hline Laurus sp. & Laurus sp. \\
\hline Magnolia sp. & Magnolia sp. \\
\hline Myrica lignitum (Ung.) Sap. & Myrica cerifera \\
\hline \multicolumn{2}{|c|}{$\begin{array}{l}\text { Myrica cf. pseudolignitum Kr. \& Weyl in Myrica sp. } \\
\text { Mad. \& Steff. }\end{array}$} \\
\hline Pinus pinastroides Unger & Pinus sp. \\
\hline Pinus sp. & Pinus sp. \\
\hline Populus cf. latior A.Br. & Populus sp. \\
\hline Populus cf. balsamoides Goepp. & Populus balsamifera \\
\hline Quercus goepperti Web. & Quercus incana \\
\hline Quercus drymeja Ung. & Quercus sp. \\
\hline Quercus mediterranea Unger & Quercus ilex-coccifera type \\
\hline Quercus neriifolia (A. Br.) & Quercus sp. \\
\hline Sapindus falcifolius A. Br. & Sapindus sp. \\
\hline cf. Symplocos sp. & Symplocos sp. \\
\hline Tilia sp. & Tilia sp. \\
\hline
\end{tabular}

analysis. In general, relatively high in floras about ten or more are climatically considered more valuable taxa. This technique is based on presence/absence of taxa instead of relative abundances. The aim of the $\mathrm{CA}$ is to establish the intervals of various climate parameters for a given fossil flora in which maximal number of NLRs of this flora can coexist; these coexistence intervals are regarded as the best description of palaeoclimate under which flora lived. The method is applied to a total of 46 samples (Fig. 6). 


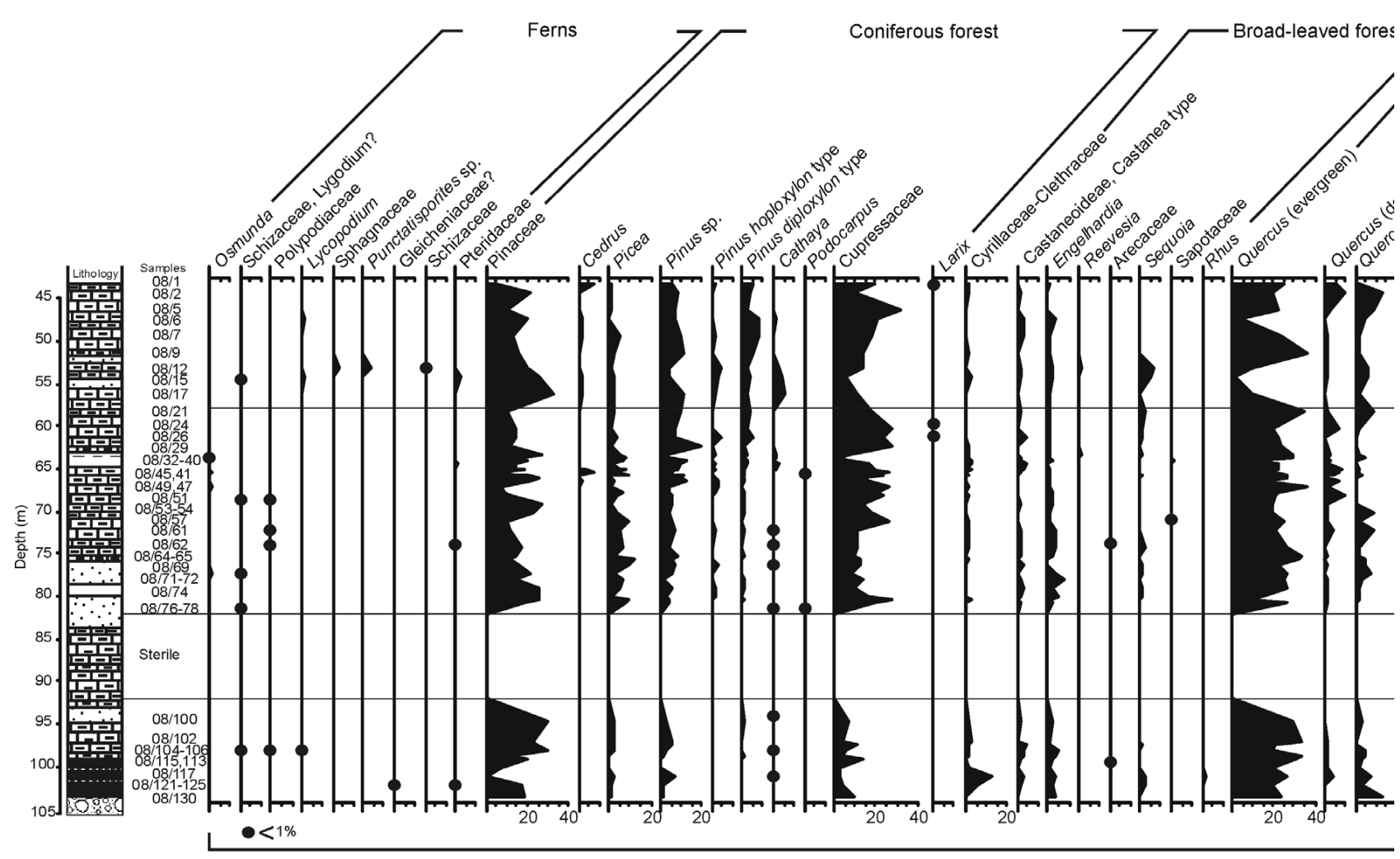

Figure 4. Pollen diagram of the Șahinali-2 core indicating percentages of floral components in samples.

The following palaeoclimate climate parameters are considered: MAT - mean annual temperature $\left({ }^{\circ} \mathrm{C}\right)$; $\mathrm{CMT}-$ mean temperature of thecoldest month $\left({ }^{\circ} \mathrm{C}\right)$; WMT mean temperature of the warmest month $\left({ }^{\circ} \mathrm{C}\right)$; MAP mean annual precipitation ( $\mathrm{mm})$; HMP - precipitation of the wettest month (mm); LMP - precipitation of the direst month (mm); WMP - precipitation of the warmest month $(\mathrm{mm})$. Also leaf flora has been subjected to the CA method to obtain quantitative palaeoclimate data, and the results are correlated with the climate records from palynological data (Table 1).

\section{Results}

\section{Pollen flora}

A total of 62 sporomorph taxa were identified and major floral components are indicated in Fig. 4 (Ivanov et al. 2002, Jiménez-Moreno et al. 2007). Diversity and percentages of spores are low, but the number of pollen and their quantities are high. Most of the taxa are recorded in low frequencies, but a few are abundant.

The detailed pollen diagram indicates high percentages of pollen grains of indeterminate Pinaceae, Pinus, Cupressaceae (mainly morpho-genus Inaperturopollenites and pollen grains of Cupressacites), evergreen Quercus and Alnus (Fig. 4). Indeterminate Pinaceae are constant and well represented in the diagram (up to $33 \%$ ). They are followed by low frequencies of other coniferous forest elements: Pinus, Cedrus, Picea, Pinus diploxylon type, P. haploxylon type, Podocarpus, Larix and Cathaya. Cupressaceae are comparatively in less quantities in the lower side of the succession where they do not exceed $12 \%$, but abundant in the higher stratigraphic levels. Among the broad-leaved forest elements evergreen Engelhardia and deciduous Castanea type constantly occur. Mixed mesophytic forest elements evergreen and deciduous Quercus and Fagus occur regularly. Evergreen Quercus are represented by high percentages and constantly more abundant than deciduous Quercus. Riparian vegetation element Alnus makes a peak reaching to $40 \%$ in the lower part, but decreases to the upper part. The pollen grains of Ulmus, Pterocarya, Carya, Platanus and Zelkova occur in low percentages, even below $1 \%$. Some taxa such as Cedrus, Cathaya, Larix, Reevesia, Sequoia, Sapotaceae, Carpinus, Parrotia persica, Oleaceae, Betula, Ilex, Ostrya, Phillyrea, Cycas, Tilia, Salix, Liquidambar and Nyssaceae occur in low percentages and discontinuously. Herbaceous plants (Cyperaceae, Sparganium, Asteraceae, Chenopodiaceae, Ephedra, Caryophyllaceae and Brassicaceae) are represented by minor quantities throughout the diagram. 
Mehmet Serkan Akkiraz • Vegetation and climate in the Miocene deposits of the Büyük Menderes Graben

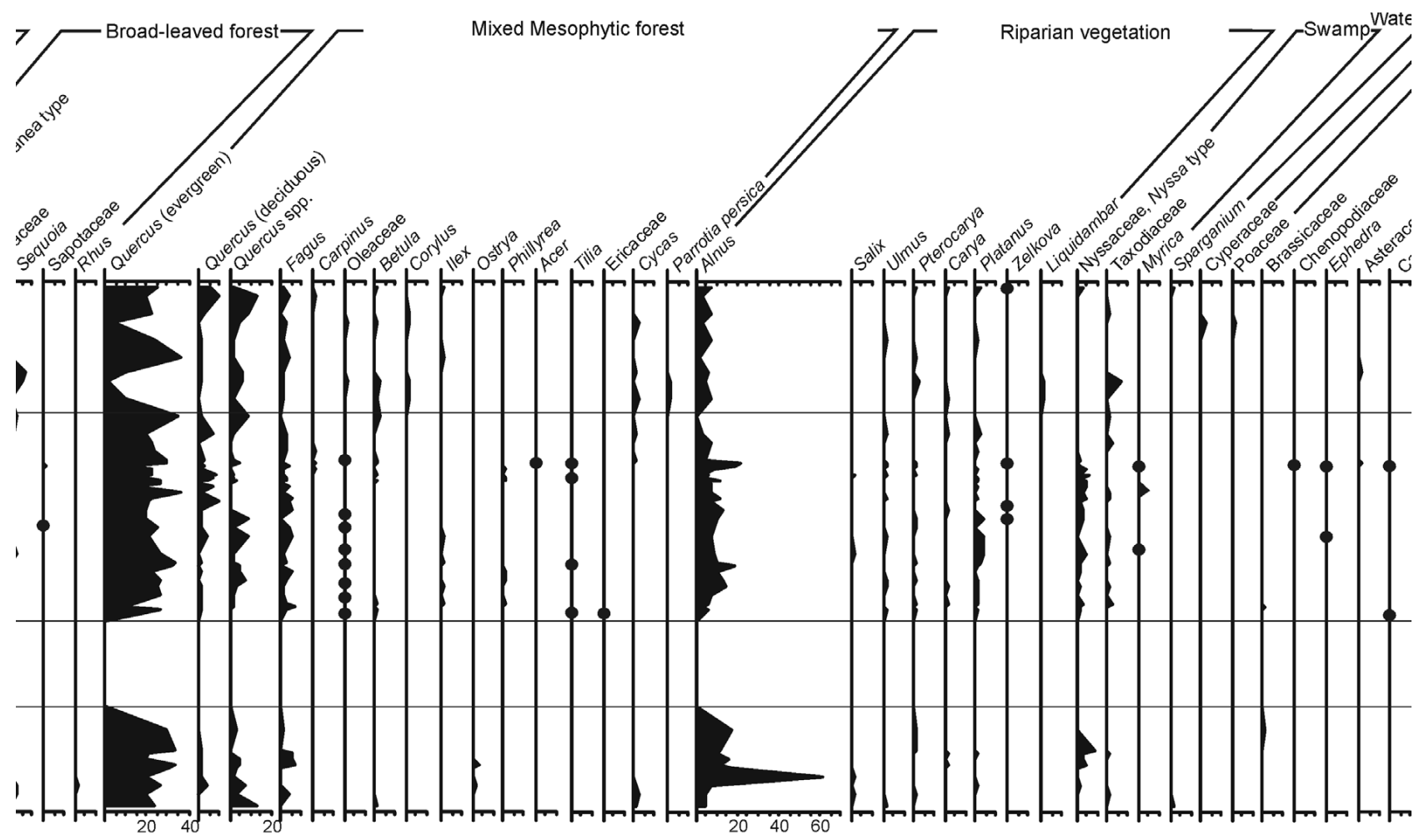

Figure 4 - continued

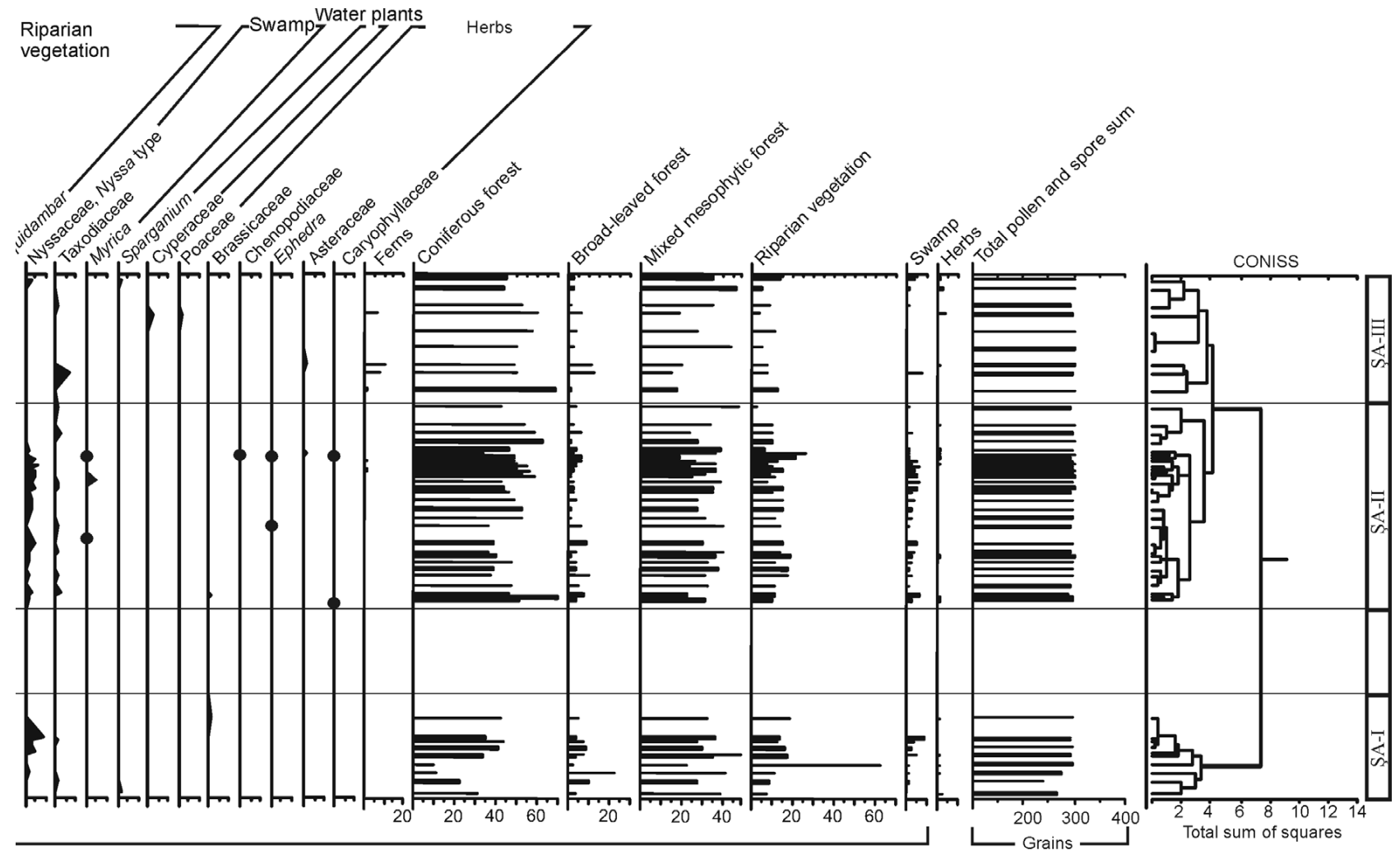

Figure 4 - continued 
Table 3. Coexistence intervals of individual samples from palynoflora.

\begin{tabular}{|c|c|c|c|c|c|c|c|c|}
\hline Samples & Number of taxa & $\operatorname{MAT}\left({ }^{\circ} \mathrm{C}\right)$ & $\mathrm{CMT}\left({ }^{\circ} \mathrm{C}\right)$ & WMT $\left({ }^{\circ} \mathrm{C}\right)$ & MAP (mm) & HMP (mm) & $\mathrm{LMP}(\mathrm{mm})$ & $\mathrm{WMP}(\mathrm{mm})$ \\
\hline 08/01 (top) & 12 & $15.6-18.4$ & $5.0-12.5$ & $24.7-28.1$ & $823-1520$ & $204-227$ & $8-41$ & $79-125$ \\
\hline $08 / 06$ & 10 & $15.6-18.4$ & $5.0-12.5$ & $24.7-28.3$ & $823-1577$ & $204-227$ & $5-41$ & $79-125$ \\
\hline 08/07 & 10 & $15.6-18.4$ & $5.0-12.5$ & $24.7-28.3$ & $823-1577$ & $204-227$ & $8-41$ & $79-125$ \\
\hline 08/09 & 11 & $15.6-21.3$ & $5.0-13.3$ & $24.7-28.3$ & $823-1595$ & $204-227$ & $8-54$ & $79-125$ \\
\hline $08 / 12$ & 13 & $15.6-21.3$ & $5.0-17.0$ & $24.7-28.3$ & $823-1520$ & $204-227$ & $5-54$ & $79-125$ \\
\hline $08 / 15$ & 16 & $15.6-18.4$ & $5.0-12.5$ & $24.7-28.1$ & $823-1520$ & $204-227$ & $5-41$ & $79-125$ \\
\hline $08 / 17$ & 13 & $15.6-18.4$ & $5.0-12.5$ & $24.7-28.1$ & $823-1574$ & $204-227$ & $8-41$ & $79-125$ \\
\hline $08 / 21$ & 11 & $15.6-21.3$ & $5.0-13.3$ & $24.7-28.1$ & $823-1520$ & $204-227$ & $8-43$ & $79-125$ \\
\hline $08 / 24$ & 11 & $15.6-21.3$ & $5.0-13.3$ & $24.7-28.1$ & $823-1520$ & $204-227$ & $8-43$ & $79-125$ \\
\hline $08 / 26$ & 13 & $15.6-21.7$ & $5.0-15.6$ & $24.7-28.1$ & $823-1520$ & $204-227$ & $5-43$ & $79-125$ \\
\hline $08 / 29$ & 10 & $15.6-21.3$ & $5.0-13.3$ & $24.7-28.3$ & $823-1520$ & $204-227$ & $8-54$ & $79-125$ \\
\hline $08 / 32$ & 14 & $15.6-20.8$ & $5.0-13.3$ & 24.7-28.1 & $823-1520$ & $204-227$ & $9-45$ & $79-125$ \\
\hline $08 / 33$ & 16 & $15.6-18.4$ & $5.0-12.5$ & $24.7-28.1$ & $823-1574$ & $204-227$ & $8-41$ & $79-125$ \\
\hline $08 / 34$ & 11 & $15.6-20.8$ & $5.0-13.3$ & $24.7-28.1$ & $823-1574$ & $204-227$ & $9-43$ & $79-125$ \\
\hline $\mathrm{t} 08 / 35$ & 13 & $15.6-20.8$ & $5.0-12.5$ & $24.7-28.1$ & $823-1520$ & $204-227$ & $9-41$ & $79-125$ \\
\hline $08 / 36$ & 15 & $15.6-18.4$ & $5.0-12.5$ & 24.7-28.1 & $823-1574$ & $204-227$ & $8-41$ & $79-125$ \\
\hline $08 / 37$ & 14 & $15.6-18.4$ & $5.0-12.5$ & $24.7-28.1$ & $823-1574$ & $204-227$ & $9-41$ & $79-125$ \\
\hline $08 / 38$ & 13 & $15.6-18.4$ & $5.0-12.5$ & $24.7-28.1$ & $823-1574$ & $204-227$ & $9-41$ & $79-125$ \\
\hline $08 / 39$ & 10 & $15.6-21.3$ & $5.0-13.3$ & $24.7-28.3$ & $823-1595$ & $204-227$ & $8-54$ & $79-125$ \\
\hline $08 / 40$ & 12 & $15.6-18.4$ & $5.0-12.5$ & $24.7-28.1$ & $823-1520$ & $204-245$ & $8-41$ & $79-154$ \\
\hline $08 / 41$ & 12 & $15.6-18.4$ & $5.0-12.5$ & $24.7-28.1$ & $823-1577$ & $204-245$ & $16-41$ & $79-125$ \\
\hline $08 / 45$ & 10 & $15.6-18.4$ & $5.0-12.5$ & $24.7-28.3$ & $823-1577$ & $204-227$ & $8-41$ & $79-125$ \\
\hline $08 / 47$ & 10 & $15.6-21.7$ & $5.0-15.6$ & $24.7-28.1$ & $823-1520$ & $204-245$ & $5-43$ & $79-180$ \\
\hline $08 / 49$ & 10 & $15.6-18.4$ & $5.0-12.5$ & $24.7-28.3$ & $823-1520$ & $204-227$ & $8-41$ & $79-125$ \\
\hline $08 / 51$ & 10 & $15.6-21.3$ & $5.0-13.3$ & $24.7-28.3$ & $823-1595$ & $204-227$ & $8-54$ & $79-125$ \\
\hline $08 / 53$ & 10 & $15.6-21.3$ & $5.0-13.3$ & $24.7-28.3$ & $823-1595$ & $204-227$ & $8-54$ & $79-125$ \\
\hline $08 / 57$ & 10 & $15.6-21.3$ & $5.0-13.3$ & $24.7-28.3$ & $823-1613$ & $204-353$ & $8-54$ & $79-163$ \\
\hline $08 / 61$ & 10 & $15.6-21.3$ & $5.0-13.3$ & $24.7-28.3$ & $823-1520$ & $204-227$ & $8-54$ & $79-125$ \\
\hline $08 / 62$ & 13 & $15.6-21.3$ & $7.7-13.3$ & $24.7-28.3$ & $1003-1520$ & $204-245$ & $8-45$ & $79-163$ \\
\hline $08 / 64$ & 10 & $15.6-20.8$ & $5.0-13.3$ & $24.7-28.1$ & $823-1520$ & $204-227$ & $9-54$ & $79-125$ \\
\hline $08 / 71$ & 10 & $15.6-23.1$ & $5.0-13.3$ & $24.7-28.3$ & $823-1520$ & $204-245$ & $5-59$ & $79-180$ \\
\hline $08 / 72$ & 10 & $15.6-21.3$ & $5.0-13.3$ & $24.7-28.3$ & $823-1520$ & $204-245$ & $8-54$ & $79-125$ \\
\hline $08 / 74$ & 11 & $15.6-20.8$ & $5.0-13.3$ & $24.7-28.1$ & $823-1520$ & $204-245$ & $9-43$ & $79-125$ \\
\hline 08/76 & 12 & $15.6-21.3$ & $5.0-13.3$ & $24.7-28.3$ & $823-1520$ & $204-245$ & $16-67$ & $79-154$ \\
\hline $08 / 77$ & 10 & $15.6-18.4$ & $5.0-12.5$ & $24.7-28.1$ & $823-1520$ & $204-227$ & $9-41$ & $79-125$ \\
\hline $08 / 78$ & 10 & $15.6-23.1$ & $5.0-12.5$ & $24.7-28.3$ & $823-1520$ & $204-353$ & $9-41$ & $79-154$ \\
\hline 08/100 & 10 & $15.6-21.7$ & $5.0-13.3$ & $24.7-28.1$ & $823-1574$ & $204-227$ & $5-43$ & $79-125$ \\
\hline 08/102 & 10 & $15.6-23.1$ & $5.0-12.5$ & $24.7-28.3$ & $823-1595$ & $204-353$ & $9-67$ & $79-154$ \\
\hline 08/104 & 11 & $15.6-21.3$ & $5.0-13.3$ & $24.7-28.1$ & $823-1520$ & $204-245$ & $8-43$ & $79-154$ \\
\hline 08/105 & 10 & $15.6-23.1$ & $5.0-13.3$ & $24.7-28.3$ & $823-1595$ & $204-353$ & $9-67$ & $79-180$ \\
\hline 08/106 & 11 & $15.6-21.3$ & $5.0-13.3$ & $24.7-28.3$ & $823-1520$ & 204-227 & $8-54$ & $79-125$ \\
\hline $08 / 113$ & 11 & $15.6-21.7$ & $7.7-15.6$ & $24.7-28.1$ & 1003-1574 & $204-323$ & $5-43$ & $79-180$ \\
\hline $08 / 115$ & 10 & $15.6-23.1$ & $5.0-13.3$ & $24.7-28.3$ & $823-1520$ & $204-353$ & $5-59$ & $79-180$ \\
\hline 08/117 & 10 & $15.6-21.7$ & $5.0-15.6$ & $24.7-28.1$ & $823-1520$ & $204-245$ & $5-43$ & $79-180$ \\
\hline 08/121-125 & 11 & $15.6-21.3$ & $5.0-15.6$ & $24.7-28.3$ & $823-1595$ & $204-353$ & $8-67$ & $79-154$ \\
\hline 08/130 (base) & 12 & $15.6-18.4$ & $5.0-12.5$ & $24.7-28.1$ & $823-1520$ & $204-227$ & $9-41$ & $79-125$ \\
\hline
\end{tabular}




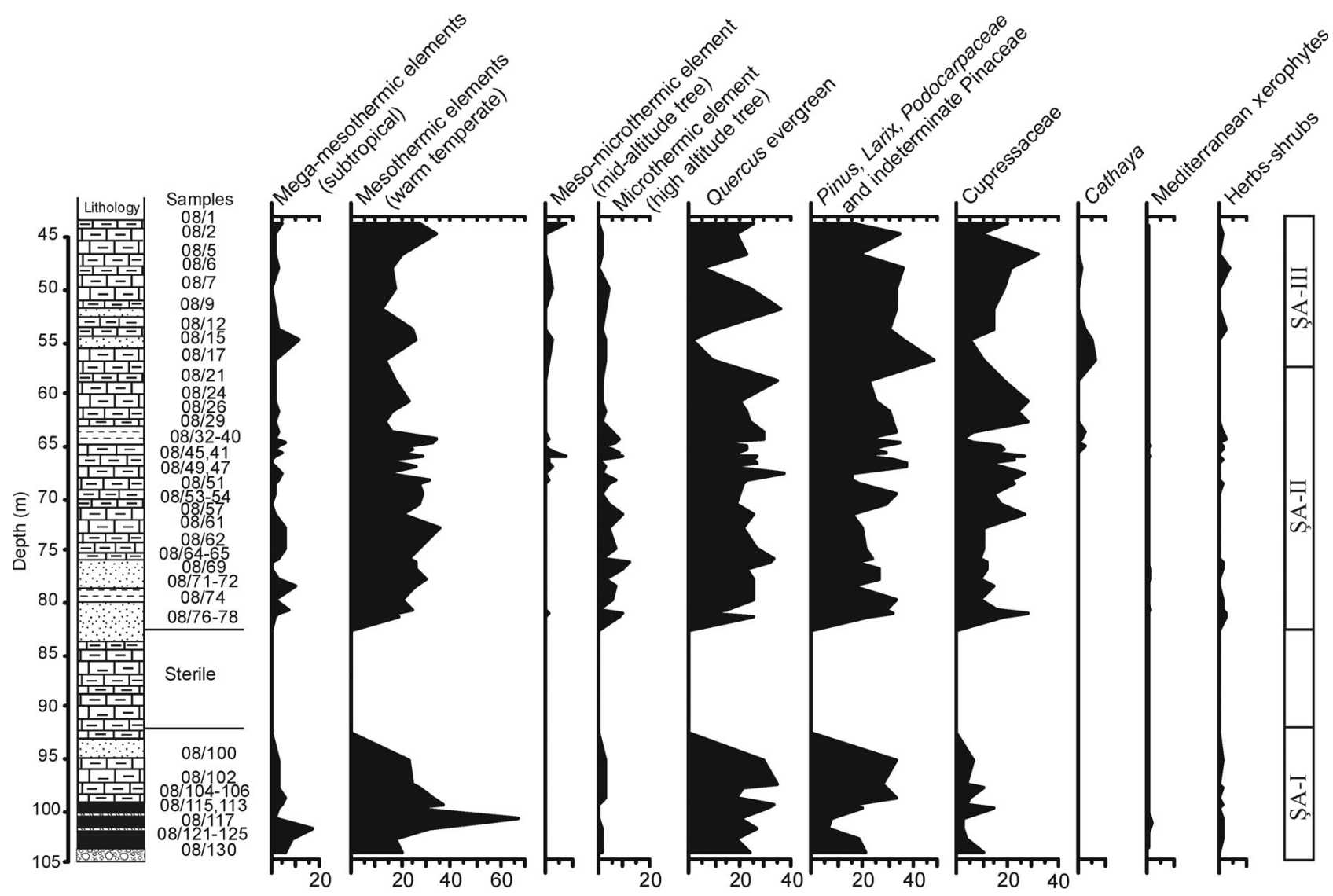

Figure 5. Synthetic pollen diagram. Pollen taxa have been grouped on the basis of ecological criteria (according Suc 1984, Jiménez-Moreno et al. 2005): Mega-mesothermic elements (subtropical): Taxodiaceae, Engelhardia, Myrica, Sapotaceae, Castanea-Castanopsis type, Cyrillaceae-Clethraceae, Reevesia, Arecaceae; Cathaya; Mesothermic elements (warm temperate): deciduous Quercus, Carya, Pterocarya, Oleaceae, Carpinus, Ostrya, Parrotia persica, Zelkova, Ulmus, Tilia, Acer, Liquidambar, Alnus, Salix, Platanus, Nyssa, Ilex, Betula, Sequoia and Fagus; Pinus, Larix, Podocarpaceae and indeterminate Pinaceae; Meso-microthermic element (cool temperate): Cedrus; Microthermic element (cool): Picea; Mediterranean xerophytes: Rhus and Phillyrea; Evergreen Quercus; Cupressaceae; Herbs-shrubs: Poaceae, Amaranthaceae-Chenopodiaceae, Asteraceae, Ephedra, Cyperaceae, Sparganium, Brassicaceae and Caryophyllaceae.

According to quantitative changes in certain sporomorphs, the pollen diagram has been divided into three pollen phases (= local pollen zones) which are corroborated by CONISS clustering via TILIA 2.0 (Fig. 4). However, due to lack of pollen grains, there is a gap in the pollen diagram between 82.15 and $95.2 \mathrm{~m}$ (samples 08/79-99).

\section{Local pollen zone ŞA-I (core depth 95.2-103.04 m; samples 08/100-130)}

This zone is characterized by the highest average content of Alnus, represented mainly by values from 5 to $12 \%$, with a maximum of $62.5 \%$ at $100.25 \mathrm{~m}$ (sample 08/115), and Cyrillaceae-Clethraceae, represented mainly by values from 1 to $5 \%$, occasionally higher $(13.46 \%$ at $101.2 \mathrm{~m}$; sample 08/117). Indeterminate Pinaceae are characterized with higher values of 0 to $30 \%$, and tend to increase towards the upper part of the zone. Evergreen oaks (Quercus, range $25.2-35 \%$ ) abundantly occur. Cupressaceae appear regularly with values of 2.5 to $12 \%$. Picea is represented with the values range from 0 to $3.8 \%$. Nyssaceae reach to the highest occurrence about $9.6 \%$ at $97.50 \mathrm{~m}$ (sample 08/102). Spores are represented by scarce grains of Schizaeceae, Gleicheniaceae?, Polypodiaceae, Pteridaceae and Lycopodium (Fig. 5). Open vegetation elements, Brassicaceae, are found in minor quantities. Low percentages of Rhus and Ostrya occur in this zone.

\section{Local pollen zone ŞA-II (core depth 57.43-82.15 m; samples 08/21-08/78)}

The diversities and percentages of spores slightly increase in this zone. Indeterminate Pinaceae have more or less similar percentages in fluctuating abundances (Fig. 5). The pollen of Cedrus, Larix, Pinus haploxylon type, Podocarpus, Reevesia, Sapotaceae, Oleaceae, Phillyrea, Acer, Tilia, Ilex, Zelkova, Chenopodiaceae, Ephedra, Asteraceae and Caryophyllaceae appear in low amounts. The pollen 

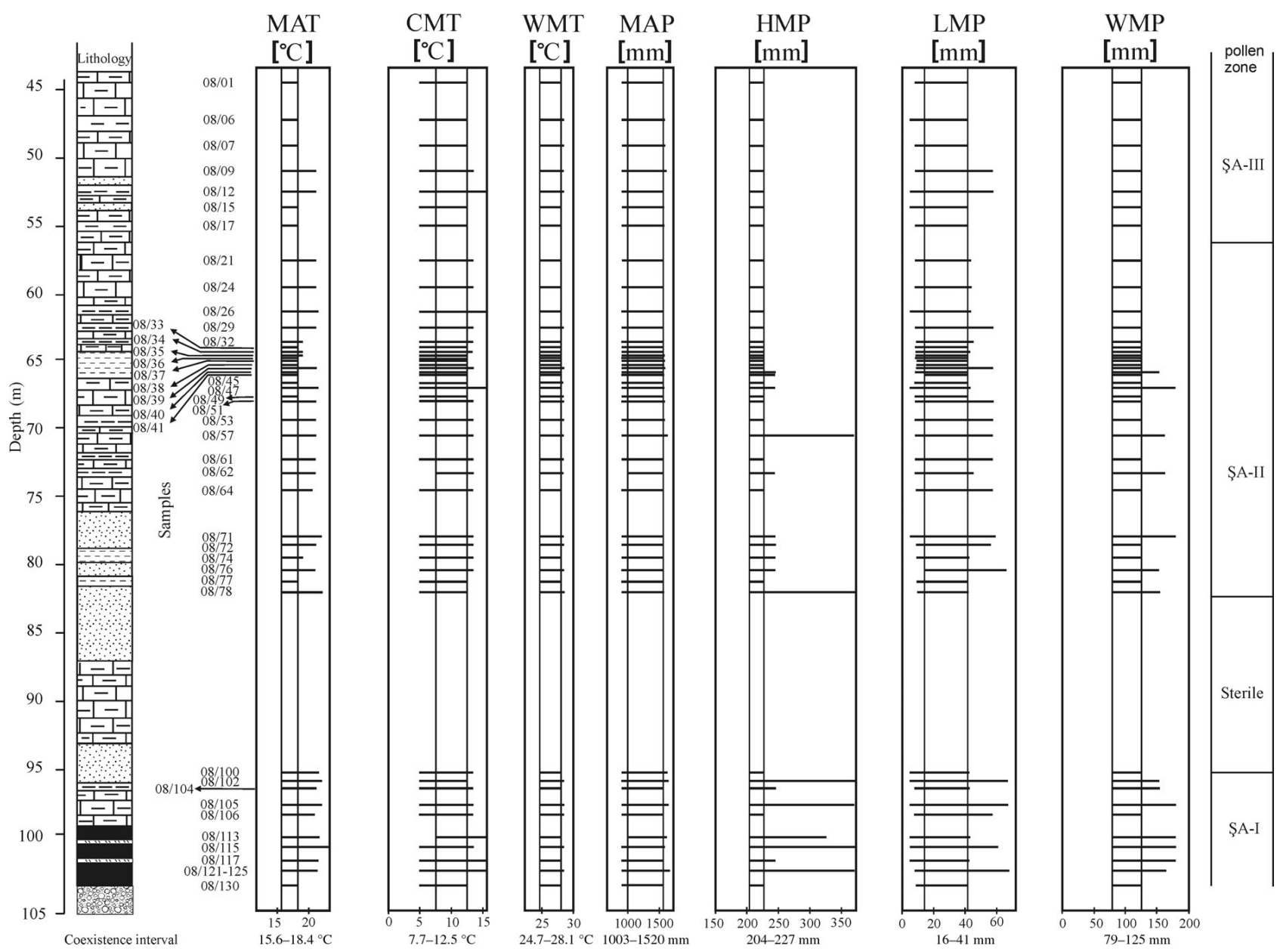

Figure 6. Coexistence intervals of each sample from the Șahinali palynoflora.

of Picea, Pinus, Pinus diploxylon type, deciduous Quercus, Platanus and Taxodiaceae have slightly increased. Picea is mainly represented by the values of 2.5 to $12.5 \%$, and has maximum values of $12.6 \%$ at $76.16 \mathrm{~m}$ (sample 08/69). The curve of Pinus reaches a peak of $20.02 \%$ at $62.5 \mathrm{~m}$ (sample 08/29). Pinus diploxylon type has slightly increased along the zone 2 . The percentages of the Cupressaceae rise significantly upwards, reaching up to 25-28\% at $80.78 \mathrm{~m}$ (sample 08/77). Whereas the percentages of Alnus mark a slight tendency to decrease and values of 7-8\% are most common, occasionally up to $21 \%$ at $63.8 \mathrm{~m}$ (sample 08/33). Also Cyrillaceae-Clethraceae decrease and values range from 1 to $2 \%$. Herbs such as Caryophyllaceae, Chenopodiaceae, Brassiacaceae, Ephedra and Poaceae are rarely observed or even single grains recorded.

\section{Local pollen zone ŞA-III (core depth 42.84-57.43 $\mathrm{m}$; samples 08/01-08/17)}

The highest percentages of the ferns are recorded in this zone. Lycopodium reaches up to $2 \%$ at $53.75 \mathrm{~m}$ and $47.4 \mathrm{~m}$ (samples 08/15 and 08/06). Sphagnaceae and unknown botanical affinity of Punctatisporites sp. also reach

Figure 7. Each illustration is accompanied by its name, sample number, depth of the Sahinali-2 core and local pollen zones. Scale bar $20 \mu \mathrm{m}$ for all photographs. • A - Osmunda, sample 08-38; depth 65.0 m; ȘA-II. • B, C - Lygodium; B - sample 08-51; depth 67,5 m; ȘA-II, C - sample 08-72; depth 78.10 m; ȘA-II. • D - Polypodiaceae, sample 08-130; depth 103.85 m; ȘA-I. • E - Sphagnaceae, sample 08-12; depth 53.25 m; ȘA-III. • F - Gleicheniaceae?, sample 08-130; depth 103.85 m; SA-I. • G - Punctatisporites sp., sample 08-12; depth 53.25 m; SA-III. • H, I - Pteridaceae; H - sample 08-15; depth 53.75 m; ȘA-III, I - sample 08-130; depth 103.85 m; ȘA-I. • J - Lycopodium sample 08-06; depth 47.40 m; ȘA-I. • K - Ephedra, sample 08-62; depth 74.4 m; SA-II. • L - Picea, sample 08-69; depth 76.1 m; SA-II. • M - Pinus haploxylon type, sample 08-17; depth 56.2 m; SA-I. • N, O - Pinus diploxylon type; N - sample 08-09; depth 50.95 m; ȘA-III, O - sample 08-07; depth 49.10 m; ȘA-III. • P - Pinus spp.; sample 08-69; depth $76.1 \mathrm{~m}$; ȘA-II. 
Mehmet Serkan Akkiraz • Vegetation and climate in the Miocene deposits of the Büyük Menderes Graben
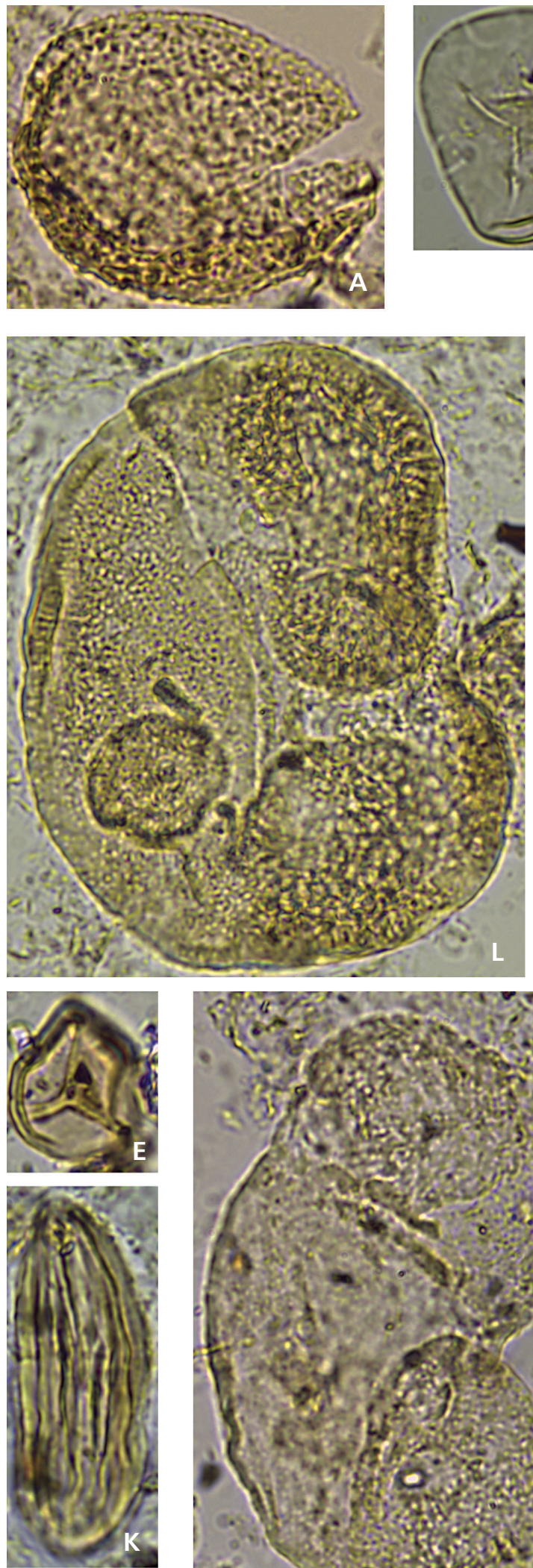

20
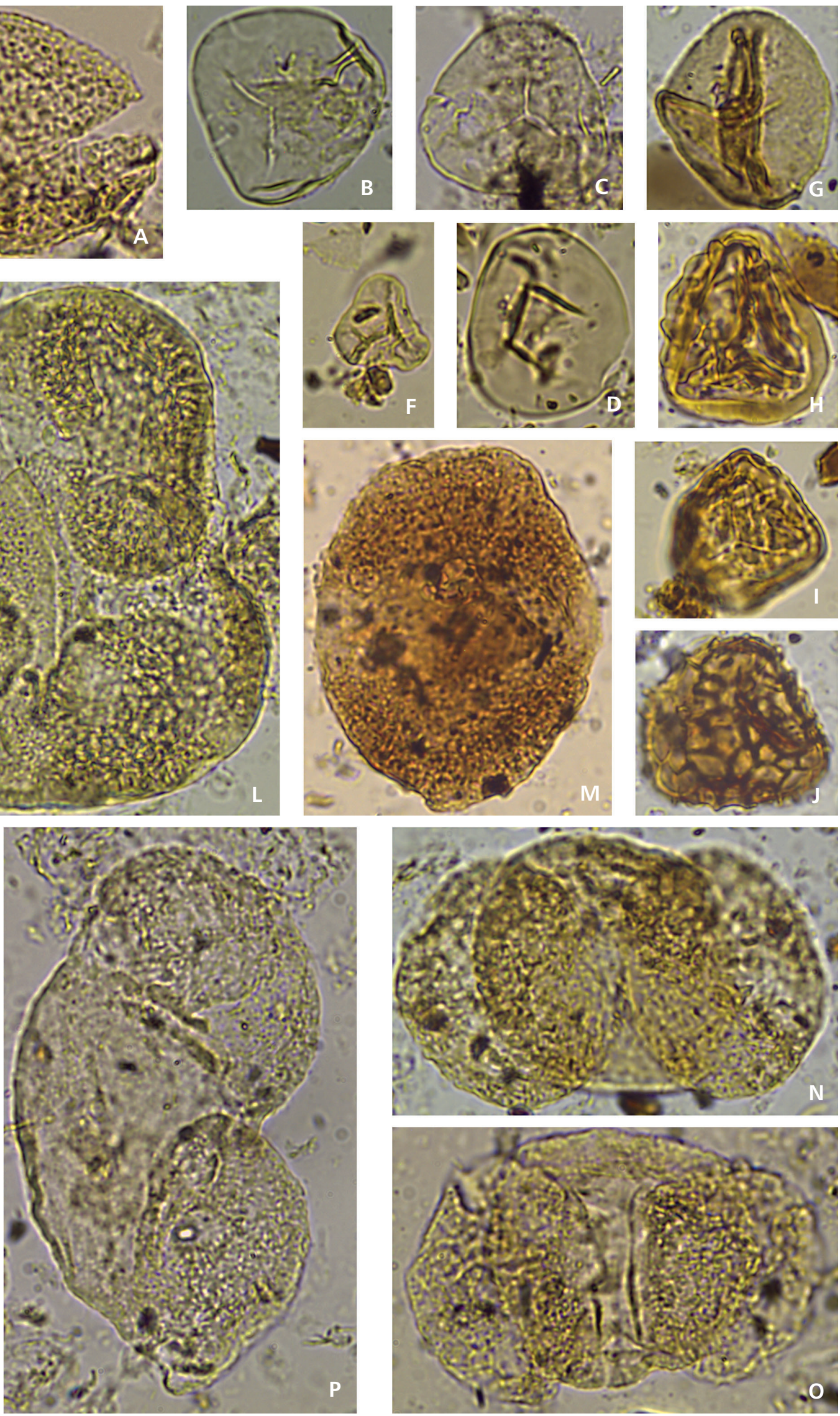
up to $4.8 \%$ and $4.9 \%$ at $53.25 \mathrm{~m}$, respectively (sample $08 / 12$ ). Pteridaceae make a peak, percentage values of $3.8 \%$ at $53.75 \mathrm{~m}$ (sample 08/15). The pollen of Corylus, Parrotia persica, Liquidambar, Cyperaceae and Poaceae appear in minor quantities. Indeterminate Pinaceae achieve their highest percentages of $32.8 \%$ at $56.18 \mathrm{~m}$ (sample 08/17). The pollen of Picea, Alnus and Platanus mark a slight tendency to decrease, whereas Pinus, Pinus diploxylon type and Cathaya have increased. Taxodiaceae reach their maximum values, $7.1 \%$ at $53.75 \mathrm{~m} \mathrm{(08/15}$ sample). Compared to other local zones, Nyssaceae are represented by low percentages. The highest percentages of Sequoia, around 6\% at $53.25 \mathrm{~m}$ (sample 08/12), were recorded in this zone.

The three local zones are very similar in having major tree genera indeterminate Pinaceae, evergreen Quercus, Pinus, Cupressaceae and Alnus. Even though there were some fluctuations in the three zones, the main types remained the same. It indicates that evergreen and deciduous mixed mesophytic and coniferous forest assemblages were dominant during the Early-Middle Miocene.

\section{Leaf flora}

Mädler \& Steffens (1979) and Gemici et al. (1993) described 32 taxa (Table 2) from the marl-dominated lithologies above the main coal seam corresponding to local pollen zones ȘA-II and ȘA-III (Fig. 3). The assemblage predominantly includes high quantities of Laurus, Cinnamomophyllum, Myrica, evergreen oaks (Quercus mediterranea and $Q$. drymeja), and alder (Alnus) (Madler \& Steffens 1979). Evergreen Quercus and Alnus are predominantly found in the palynological data as well. Subtropical climate was suggested on the basis of thermophilous elements such as Cercis, Laurus and evergreen Quercus. Also Gemici et al. (1993) indicated that mixed mesophytic forest assemblage was dominated by oaks. Pinaceae constantly occurred in all strata. Swamp vegetation was represented by Glyptostrobus europaeus and Myrica lignitum.

\section{Palaeovegetation}

On the basis of palynomorphs and leaves, it is possible to draw a general picture of the different vegetation units sur- rounding of Șahinali open cast mine for the whole sequence. In the area, forested environments should have covered much of the landscape for the time of deposition of sediments, as coniferous forest and evergreen to deciduous mixed mesophytic forests were dominant in the succession (Fig. 4). Broad-leaved forest and riparian vegetation elements are of secondary importance. Ferns, herbaceous plants and swamp elements occur in minor amounts (Fig. 4). In the assemblages evergreen Quercus and coniferous forest Cupressaceae were widespread. In contrast, lower percentages of mesothermic elements with contributions by deciduous Quercus, Oleaceae, Acer, Tilia and Betula were recorded. Their limited occurrence indicates lowlands and mid-altitude upland environments that also permit the growth of Fagus, Carpinus and Ilex. In these forests some thermophilous evergreen broad-leaved plants such as Arecaceae, Engelhardia and Reevesia survived. Evergreen and deciduous mixed forest assemblages are well evidenced by macrofloral records of Laurus, Laurophyllum, sclerophyllous oaks (Quercus mediterranea and Q. drymeja), Carya serraefolia, Castanea kubinyii, Betula subpubescens, Diospyros cf. anceps. Diospyros sp., Magnolia sp., Symplocos sp., Fraxinus sp., Acer sp., Tilia sp., and certain species of Fagus (e.g., F. attenuata and F. orientalis) (Table 2) and microfloral records of Cyrillaceae-Clethraceae, Engelhardia, Castanea, Sapotaceae, deciduous Quercus, Fagus, Carpinus, Betula, Parrotia persica, Ostrya and Acer (Fig. 4). Also, the palaeo-lake was surrounded by dense hydrophilous trees such as Alnus (both micro- and macrofloras), Salix, Nyssaceae, Taxodiaceae, Myrica, Liquidambar (microfloral record) and the azonal element Populus balsamifera as NLR of P. balsamoides (macrofloral record). Alnus, as a component of wetland forest community presents changing percentages from the lower side to the top of the succession (Fig. 4). The azonal elements Glyptostrobus europaeus and Myrica lignitum and evergreen broad-leaved plants Daphnogene may also have been part of the wetland gallery forest. The understorey vegetation was composed of different kinds of ferns in low quantities. The pollen of hygrophilous plants like sedges (Cyperaceae) and cattails (Sparganium) are poorly presented in the pollen spectra. Herbaceous plants including Poaceae, Chenopodiaceae, Brassicaceae, Caryophyllaceae, Ephedra and Asteraceae played a minor role in the assemblage due to their limited distribution. According to Strömberg et al. (2007), open habitats developed in

Figure 8. A, B - Cathaya; A - sample 08-76; depth 80.4 m; ȘA-II, B - sample 08-69; depth 76.1 m; ȘA-II. •C - Cedrus, sample 08-01; depth 42.85 m; ȘA-III. • D - Podocarpus, sample 08-76; depth 80.4 m; ȘA-II. • E, F - Sequoia, sample 08-62; depth 74.8 m; ȘA-II. • G - Cycas sample 08-24; depth 59.75 m; ȘA-II. • H, I - Taxodiaceae; H - sample 08-62; depth 74.8 m; ȘA-II, I - sample 08-21; depth 57.45 m; ȘA-II. • J-L - Cupressaceae; J, K - sample 08-21; depth 57.45 m; ȘA-II, L - sample 08-09; depth 50.95 m; ȘA-III. • M - Poaceae, sample 08-115; depth 100.25 m; ȘA-I. • N, O - Liriodendron; N - sample 08-06; depth 47.40 m; ȘA-III, O - sample 08-121; depth 102.2 m; ȘA-I. • P - Cyperaceae, sample 08-06; depth 47.40 m; ȘA-III. • Q - Sparganiaceae, sample 08-117; depth 101.2 m; ȘA-I.・R - Myrica, sample 08-47; depth 66.8 m; ȘA-II. 

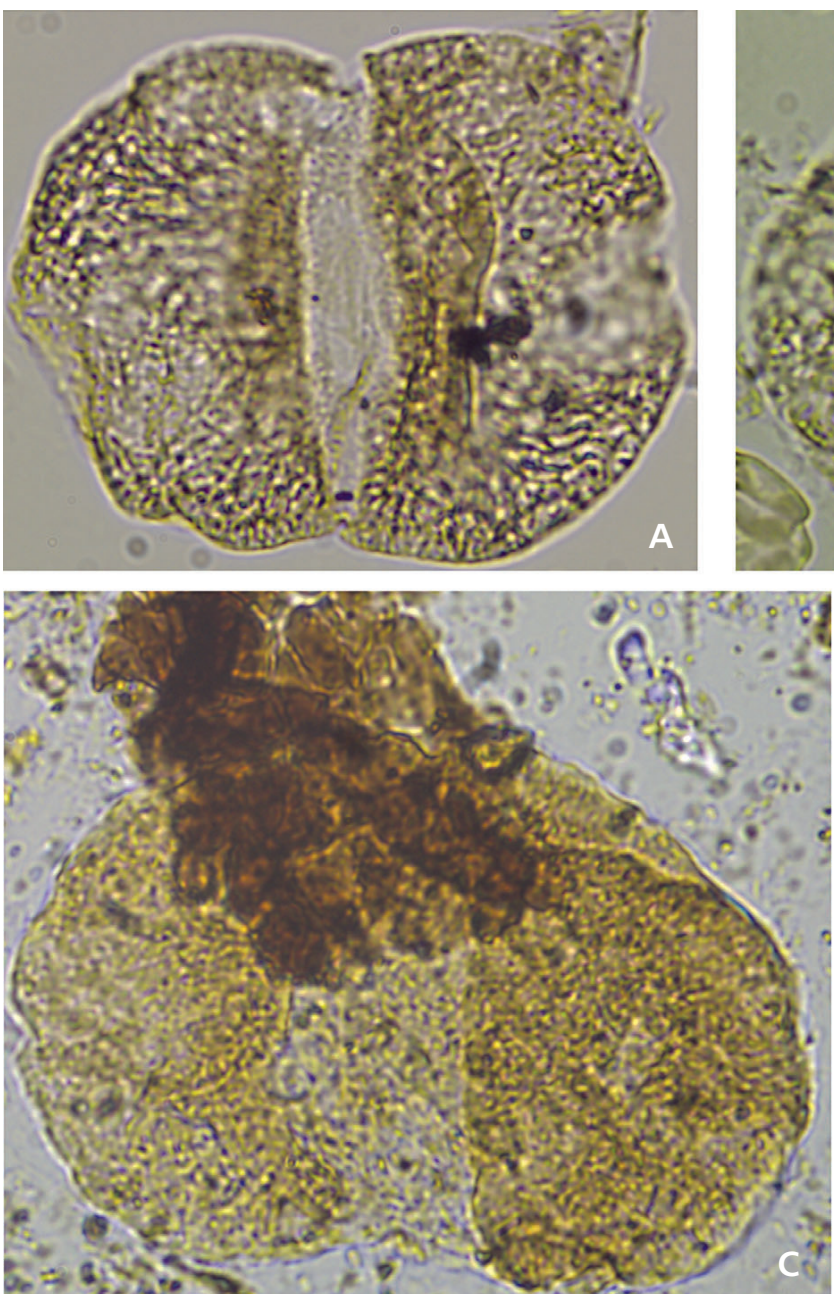
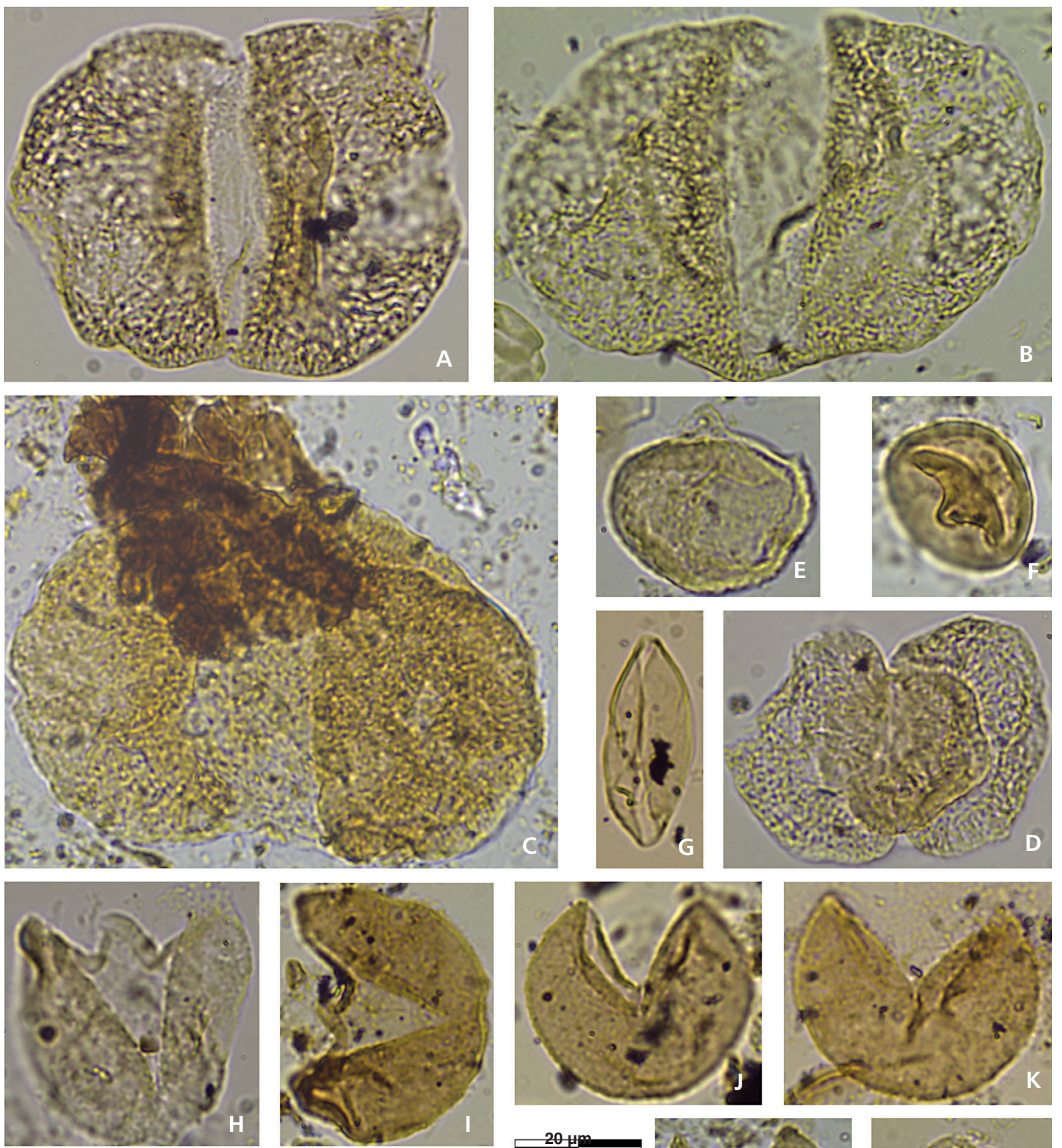

20
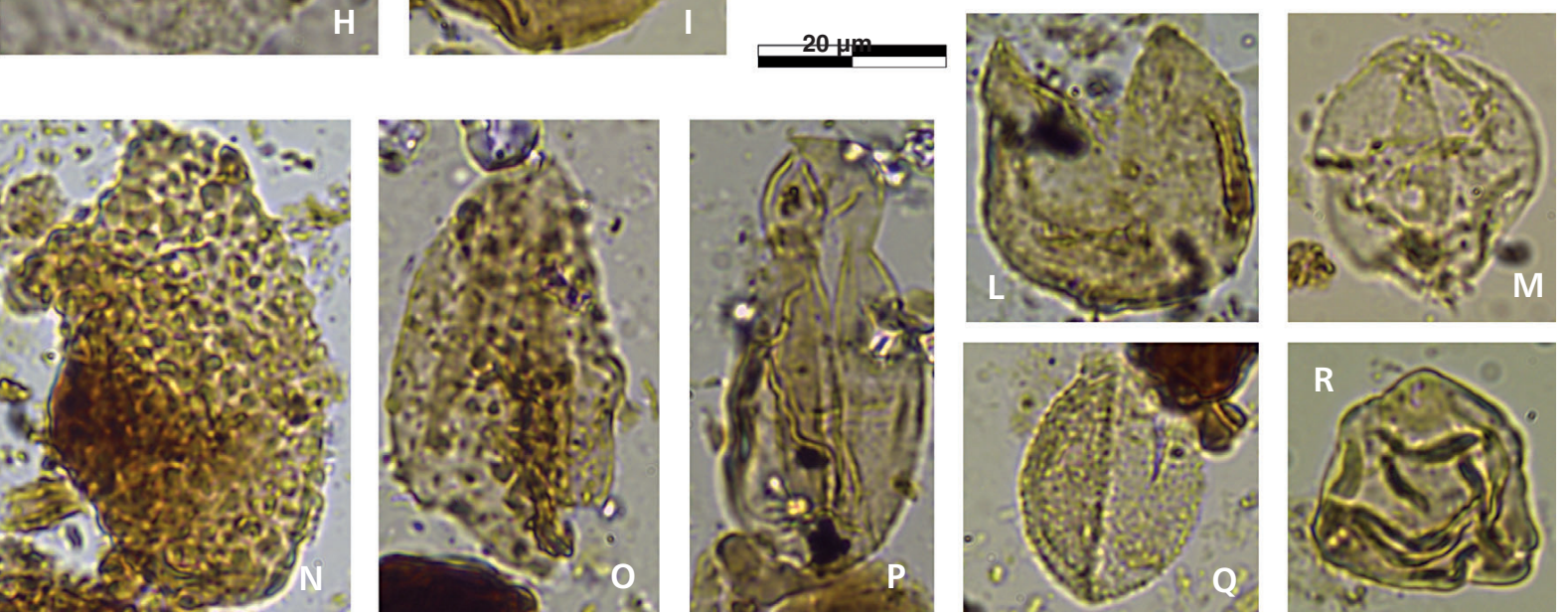
Asia Minor (Turkey) beginning already in the Early Miocene based on phytolith studies. But, analyses of Anatolian pollen profiles document an increasing abundance of open vegetation taxa only during the Tortonian (Benda et al. 1974, Akgün \& Akyol 1999, Akgün et al. 2000, Akgün et al. 2007, Kayseri \& Akgün 2008, Akkiraz et al. 2011). This may indicate a general reduction in tree cover and predominance of open-habitat grasses throughout the Miocene in Turkey. Low quantities of herbaceous plants indicate that open areas were not widespread in the Șahinali area during the Early-Middle Miocene.

On more elevated parts, mid-high altitude elements are confirmed by high quantities of indeterminate Pinaceae and low amounts of Cedrus, Picea, Podocarpus, Larix and Cathaya. However, low quantities of these taxa represented in the pollen records during the Early-Middle Miocene may be interpreted as owing to low altitude of the surrounding mountains or distance of a mountain range. In other words, although palaeogeographic reorganizations took place in global scale, Miocene tectonic movements had no significant influences since the floras included low amounts of high altitude conifers and sediments are more or less uniform and almost horizontally layered. Indeterminate Pinaceae are abundant probably due to capacity of saccate pollen for long-distance transport (Suc \& Drivaliari 1991).

Altogether, changes in quantitative values of individual pollen taxa permit us to distinguish three stages in the development of the fossil vegetation. The first includes pollen spectra from 95.2 to $103.04 \mathrm{~m}$ corresponding to local pollen zone S,A-I and is characterized by flooded forests related to high water table (Nyssaceae and Alnus) and comparatively low quantities of conifers and herbs. Also mesothermic elements are dominant (Fig. 5).

The second stage ( 57.43 to $82.15 \mathrm{~m}$ ) is mainly characterized by higher percentages of conifers, and accompanied by a slight increase in the abundance of mixed mesophytic forests. Swamp and riparian elements have more or less similar percentages. However, during the pollen zones ȘA-II and ȘA-III, an increase of Larix, Corylus, Betula and Ephedra has been observed. The group of mesothermic elements is predominant during the ȘA-II (Fig. 5). In contrast, the group of meso-microthermic and microthermic elements slightly increases. Pollen of Cedrus and Picea attain higher values.

In the third stage (42.84 to $57.43 \mathrm{~m}$ ), a reduction in proportion of Alnus and Nyssaceae has been observed that may indicate a decrease of flooded settings. Compared to the previous pollen zones, high quantities and biodiversities of spores occur in third stage.

In general, the plant taxa found at Șahinali open cast mine are similar to those found today in southeastern Mediterranean region with woodland xeric variety of Quercus, pines, Olea europaea var. oleaster, Ceratonia siliqua, Nerium oleander, Ulmus glabra, Juniperus, Poaceae and other herbs (Roberts \& Wright 1993).

\section{Palaeoclimate evolution using the CA method}

In this section, quantitative palaeoclimate data from the CA based on micro- and macrofloras are presented and correlated with palaeovegetation.

For microflora, the individual analyses of all samples provide information about possible brief climate modifications within the studied interval. As the resolution and the reliability of the resulting coexistence intervals increase with the number of taxa included in the analysis, some samples with lower than 10 taxa were not included in the climate calculations (Bruch \& Mosbrugger 2002, Bruch \& Zhilin 2007) (Table 3).

The climate parameters have been determined for 46 individual palynofloral assemblages from samples 08/01 to 08/130 (Fig. 6 and Table 3). Although some samples have yielded wider coexistence intervals than others, all coexistence intervals from the 46 samples overlap. However, the coexistence intervals are mostly similar for each sample and give no indication for climate changes from ȘA-I to

Figure 9. A, B - Engelhardia; A - sample 08-53; depth 68.80 m; ȘA-II, B - sample 08-115; depth 100.25 m; ȘA-I. C - Reveesia, sample 08-12; depth $53.25 \mathrm{~m}$; S A-III. •D - Carya, sample 08-76; depth $80.4 \mathrm{~m}$; ȘA-II. $\bullet$ E - Tilia, sample 08-41; depth $65.35 \mathrm{~m}$; S A-II. • F, G - Betula; F- sample 08-15; depth 53.75 m; SA-III, G - sample 08-76; depth 80.4 m; ȘA-II. • H - Alnus, sample 08-76; depth $80.4 \mathrm{~m}$; ȘA-II. • I - Zelkova, sample 08-38; depth 65.0 m; ȘA-II. • J - Ulmus, sample 08-62; depth $74.8 \mathrm{~m}$; S S-II. • K - Pterocarya, sample 08-57; depth $70.85 \mathrm{~m}$; S, A-II. $\bullet$ L, M - Corylus; L - sample 08-12; depth 53.25 m; ȘA-III, M - sample 08-104; depth 98.0 m; ȘA-I. • N, O - Quercus spp.; N - sample 08-07; depth 49.10 m; ȘA-III, O - sample 08-21; depth 57.45 m; SA-II. • P-R - evergreen Quercus; P - sample 08-26; depth 61.30 m; SSA-II, Q - sample 08-09; depth 50.95 m; SSA-III, R - sample 08-40; depth $65.10 \mathrm{~m}$; S S-II. • S, T - Platanus, sample 08-62; depth $74.8 \mathrm{~m}$; ȘA-II. • U, V - Salix; U - sample 08-45; depth $66.2 \mathrm{~m}$; SA-II, V - sample 08-115; depth 100.25 m; ȘA-I. • W - Oleaceae, sample 08-45; depth 66.2 m; ȘA-II. $・ X-R h u s$, sample 08-117; depth 101.2 m; ȘA-I. • Y, Z - deciduos Quercus; Y - sample 08-62; depth 74.8 m; ȘA-II, Z - sample 08-69; depth $76.1 \mathrm{~m}$; ȘA-II. • AA, BB - Oleaceae; AA - sample 08-47; depth 66.80 m; ȘA-II, BB - sample 08-49; depth $67.1 \mathrm{~m}$; ȘA-II. • CC, DD - Phillyrea; CC - sample 08-38; depth $65.0 \mathrm{~m}$; ȘA-II, DD - sample 08-69; depth 76.1 m; ȘA-II. •EE, FF - Castanea, sample 08-117; depth $101.2 \mathrm{~m}$; S A-I. • GG - Parrotia persica, sample 08-15; depth 53.75 m; ȘA-III. • HH - Fagus, sample 08-49; depth $67.1 \mathrm{~m}$; SA-II. • II, JJ - Nyssa; II - sample 08-38; depth 65.0 m; SA-II, JJ - sample 08-76; depth 80.4 m; SA-II. $・$ KK - Acer, sample 08-106; depth 98.75 m; ȘA-I. •LL - Chenopodiaceae, sample 08-76; depth 80.4 m; ȘA-II. $・$ MM, NN - Caryophyllaceae; MM - sample 08-76; depth 80.4 m; ȘA-II, NN - sample 08-78; depth 81.2 m; ȘA-II. • OO - Ilex, sample 08-01; depth 42.85 m; ȘA-III. • PP - Sapotaceae, sample 08-12; depth 53.25 m; ȘA-III. 
Mehmet Serkan Akkiraz • Vegetation and climate in the Miocene deposits of the Büyük Menderes Graben
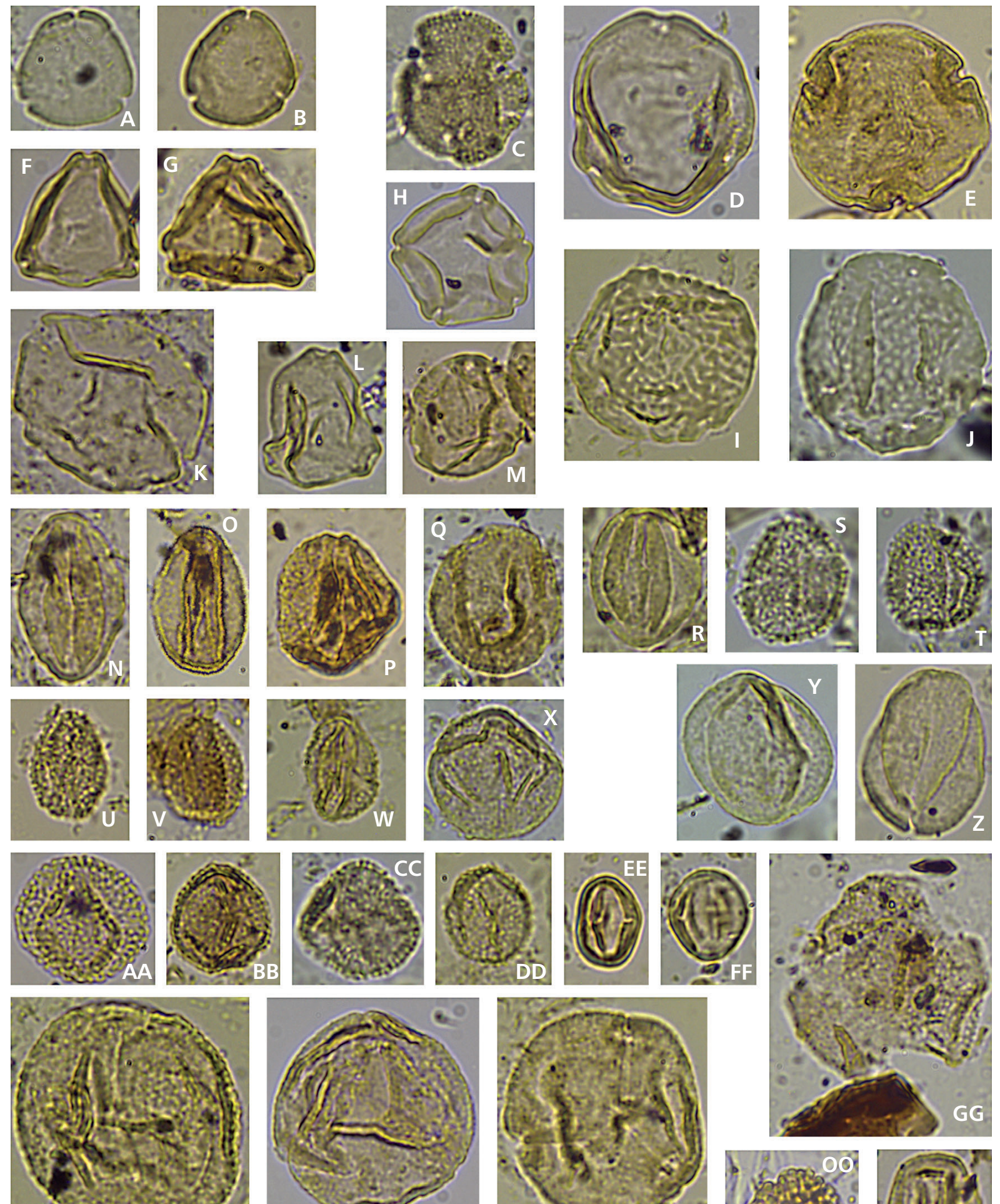

HH
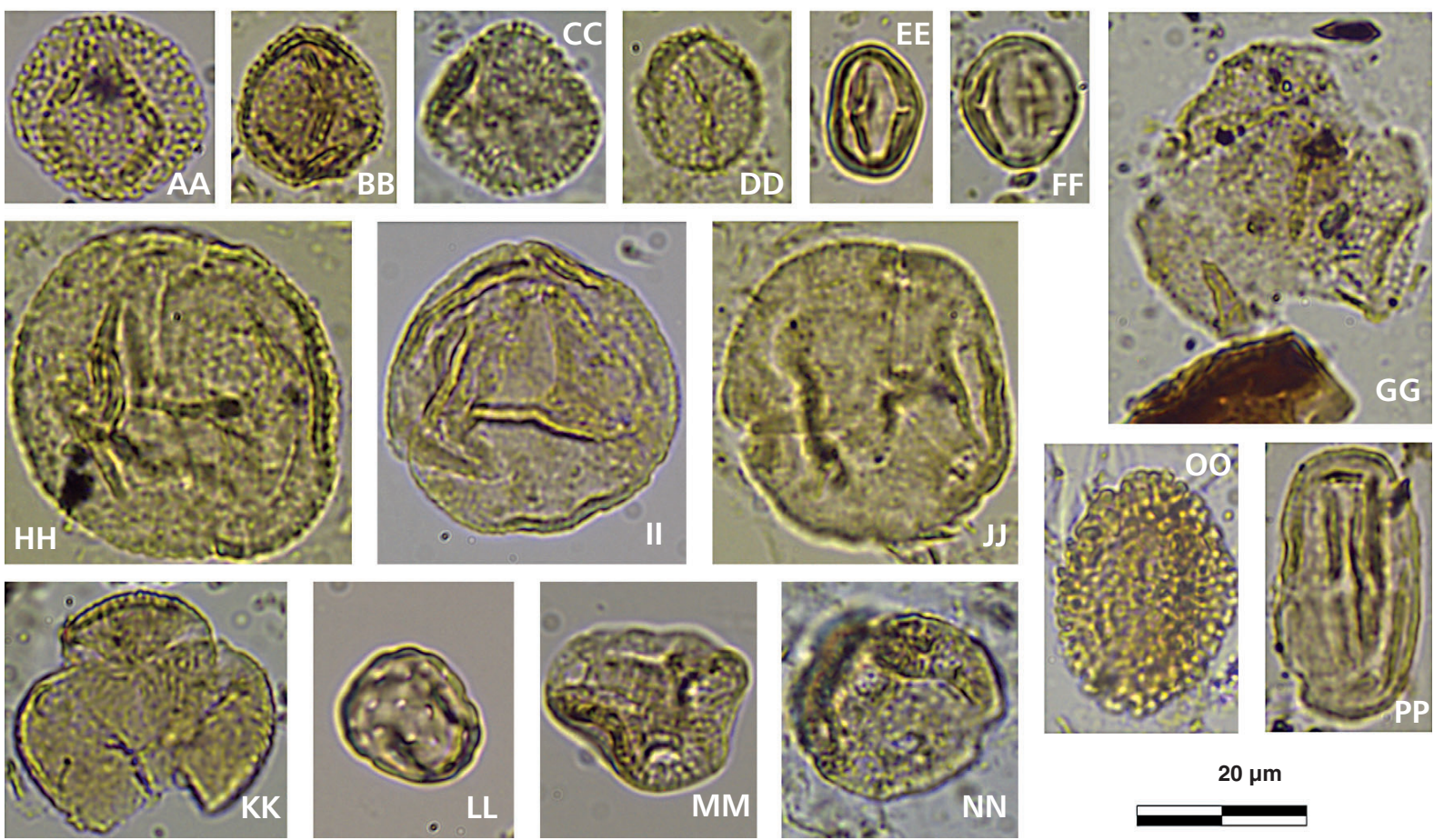

$20 \mu \mathrm{m}$ 
ȘA-III. Using the combined samples, the values obtained are 15.6 to $18.4^{\circ} \mathrm{C}$ for MAT, 7.7 to $12.5^{\circ} \mathrm{C}$ for CMT, 24.7 to $28.1^{\circ} \mathrm{C}$ for WMT, 1003 to $1520 \mathrm{~mm}$ for MAP, 204 to $227 \mathrm{~mm}$ for HMP, 16 to 41 for LMP, and 79 to $125 \mathrm{~mm}$ for WMP (Table 1). Although some samples yield wider coexistence intervals, the climate analysis of most of the samples points to a rather constant climate.

The macroflora analyzed from the same area (Madler \& Steffens 1979, Gemici et al. 1993) contains a total of 32 taxa, 17 of which were used for calculating the coexistence intervals (Table 2). The values obtained 14.4 to $15.4{ }^{\circ} \mathrm{C}$ for MAT, 5.6 to $7{ }^{\circ} \mathrm{C}$ for the CMT, 26.4 to $27.7^{\circ} \mathrm{C}$ for WMT, 1031 to $1171 \mathrm{~mm}$ for MAP, 124 to $134 \mathrm{~mm}$ for HMP, 10 to $11 \mathrm{~mm}$ for LMP, and 90 to $94 \mathrm{~mm}$ WMP (Table 1).

Comparing the quantitative palaeoclimate data from palynofloras and leaf flora, in general the coexistence intervals from these two datasets are close to each other and mostly overlap, although the taxa that border the coexistence intervals in the two data sets are different (Table 1). Both datasets are good in agreement, implying internal consistency in the method. In general, the CA on the basis of palynoflora yields wider coexistence intervals than on leaf floras (Mosbrugger \& Utescher 1997, Liang et al. 2003). This is believed to be related to the fact that NLRs of Paleogene and Neogene palynomorphs are frequently determined only as family whereas nearest living relatives of Paleogene and Neogene leaves are more reliably identified to specific and generic level.

Indeed, large quantities of evergreen Quercus in the pollen records imply that the palaeoclimate may have been warm with mild winters. In the assemblages, subtropical element, Nyssa, occur steadily in minor percentages throughout the pollen record. In contrast, the mixture of deciduous elements (deciduous Quercus, Alnus, Betula, Carpinus, Carya, Corylus, Platycarya, Ulmus) in the pollen assemblage would tend to suggest a more temperate climate with a cold season. This conflict may be interpreted by palaeogeographic elevation which permitted to develop the vegetation from basin (palaeo-lake) to upland environment or climate cooling. However, several thermophilous plants such as Cyrillaceae-Clethraceae, Engelhardia, Reveesia, Arecaceae, Sapotaceae, Taxodiaceae and Myrica lived at low elevations. Meso-microthermic element Cedrus indicates the establishment of drier and cooler episodes. According to mesothermic element Ostrya, it is an evidence of the existence of drier and sunny biotop. Also Mediterranean plant evergreen Quercus may indicate in certain seasonality in precipitation or xerophilous azonal vegetation type (Utescher et al. 2007, Jiménez-Moreno et al. 2008). Therefore, it can be assumed the vegetational development in the Early-Middle Miocene of the Sahinali open cast mine is independent from climate. All climate variables appear to be consistent and indicate warm-temperate and humid climate.
As indicated in the palaeovegetation chapter, herbaceous communities such as Poaceae, Chenopodiaceae, Brassicaceae, Caryophyllaceae, Ephedra and Asteraceae had limited a distribution. With regard to Ephedra, its presence indicates aridity that may be supported by LMP (10-11 mm) based on leaf flora. Today, Ephedra grows in arid and semiarid areas. On the other hand, abundances of herbaceous taxa were reported in southeastern Mediterranean area by Ivanov et al. $(2002,2007)$ and JiménezMoreno et al. (2007) who pointed out drier climate. However, minority of herbaceous plants defined in this study points to the absence of prevalent dry conditions.

Modern climate the mean values of Aydin surrounding can be comparable with the fossil ones. Precipitation estimates of Early-Middle Miocene seem to be higher than today (Table 1). However, it should be considered that palaeoclimate and precipitation values may vary considerably over short distances, especially if there is mountainous relief near the basin. Overall, the floral records suggest that throughout the studied time-interval the palaeoclimate was of a relatively stable warm-temperate and summermoist type. Sandy and muddy beds in the Sahinali sequence may imply hillwash owing to high annual rainfall and streams.

\section{Comparison with floras of neighboring areas}

Floral data from the Miocene deposits in western Turkey provide valuable information for possible correlation.

Micro- and macrofloristic studies on the Miocene sediments of Kütahya area (Seyitömer and Tunçbilek sub-basins) were made by Nebert (1962), Mädler \& Steffens (1979), Yavuz-Iș1k (2007) and Akkiraz et al. (2011) (Fig. 1A). In the Seyitömer Sub-basin, there are several common and widespread taxa, such as conifers, undeterminable Pinaceae, Pinus Picea, Cedrus and Cupressaceae, deciduous broad-leaved forest element Castanea-Castanopsis and mixed mesophytic forest element evergreen Quercus. The Seyitömer palynoflora appears to resemble local pollen zones ȘA-II and ȘA-III of the Șahinali palynoflora due to abundances of above mentioned taxa, but differs in the rich occurrence of ferns such as Polypodiaceae and Osmunda.

Palynoflora of the Tunçbilek Sub-basin was first examined by Akkiraz et al. (2011) who determined high quantities of Alnus, Arecaceae, undeterminable Pinaceae, Cupressaceae, Polypodiaceae and Osmunda. Abundances of Alnus in the ȘA-I and Tunçbilek palynoflora are concordant, but it is difficult to correlate in detail.

The Early-Middle Miocene fossil assemblage from the Kütahya area (Seyitömer and Tunçbilek sub-basins) described by Nebert (1962) and Madler \& Steffens (1979) is species-poorer in the leaf record. The following leaf flora 
was determined: Laurophyllum pirimigenium, Fraxinus, Diospyros brachysepala, Fagus attenuate, Myrica lignitum, Sciadopits tertiaria Taxodium dubium, Taxodiaceae, Glyptostrobus, Lauraceae, Engelhardia, Zelkova and Nerium. In the Kütahya area, the absence of Populus and Sapindus is remarkable. However, the floras of the Kütahya and Șahinali areas share the presence and sometimes abundance of Myrica lignitum, Fagus attenuate and Glyptostrobus.

The Early-Middle Miocene pollen flora of the İzmirTire area (Fig. 1A) is dominated by Polypodiaceae, Pteris, Pinaceae, Cupressaceae, Taxodiaceae, Myricaceae, Engelhardia Castanea, evergreen Quercus, Oleaceae Alnus, Ulmus and Carya (Emre et al. 2011). Local zone ȘA-I of the S,ahinali palynoflora is comparable with the Tire palynoflora, but smaller amounts of ferns, Polypodiaceae and Pteris, riparian elements such Ulmus and Carya were recorded in the Șahinali palynoflora.

Macroflora of the Tire area was studied by Gemici et al. (1992). A limited number of leaves are shared with the macroflora of the Șahinali area: Pinus, Fagus orientalis, Quercus goepperti, cf. Q. neriifolia, Acer and Fraxinus, Daphnogene polymorpha, Populus latior, and Sapindus falcifolius.

Middle Miocene microflora of the Manisa-Çıtak area (Fig. 1A) was studied by Akgün \& Akyol (1987) who indicated high proportions of Polypodiaceae and riparian element Alnus. In assemblage, deciduous Castanea, evergreen Engelhardia and mixed mesophytic forest element Quercus constantly occurred but in low amounts. Local zone S,A-I of the Șahinali palynoflora can be correlated with the Manisa-Çitak palynoflora.

Gemici et al. (1991) described rich micro- and macrofloras of the Soma area (Fig. 1A). Local pollen zones ȘA-II and ȘA-III of the Șahinali palynoflora are comparable with the Soma palynoflora that is mainly characterized by Polypodiaceae, Taxodiaceae, Pinaceae, Engelhardia, Quercus and Castanea and Cyrillaceae-Clethraceae.

Macroflora of the Soma area shares even more taxa with Șahinali. Nothworthy are Pinus, Quercus drymeja, Q. mediterranea, Laurophyllum primigenium, Daphnogene polymorpha, Cinnamophyllum scheuchzeri, Magnolia, Sapindus falcifolius, Carya serraefolia, Myrica lignitum, M. pseudolignitum, Glyptostrobus europaeus and Tilia. On the other hand, some elements such as Fagus orientalis, F. attenuata, Populus cf. balsamoides, P. cf. latior, Quercus goepperti and Q. neriifolia in the Șahinali area were not recorded in the Soma area.

These studies of the micro- and macrofloras from the Miocene lacustrine sediments in western Turkey (Nebert 1962, Madler \& Steffens 1979, Akgün \& Akyol 1987, Gemici et al. 1991, Akgün et al. 2007, Yavuz-Iș1k 2007, Akkiraz et al. 2011) show a flora dominated by evergreen and deciduous mixed plant assemblages and coniferous el- ements indicative of vegetation that is qualitatively very similar to the floras of the Sahinali area. This is indicative for the homogeneity of the floral composition in western Anatolia.

Also, micro- and macrofloras in the Șahinali coalfield and above-mentioned locations contain limited herbaceous component. Although open herbaceous formations in southern Mediterranean area are known since the Burdigalian (Suc et al. 1995a, b; Jiménez-Moreno 2005; Strömber et al. 2007), herbaceous plant communities in western Turkey had a very restricted distribution above mentioned areas where the open environments had not developed.

\section{Conclusions}

Palynomorphs recovered from the Șahinali coalfield and previous records of leaves revealed a rich and diverse flora. Our results show that during the Early-Middle Miocene the foothills of the area were mainly covered with dense coniferous forest taxa (e.g., indeterminate Pinaceae, Cupressaceae and Pinus), evergreen Quercus and Alnus. Herbs, shrubs and water plants had limited distribution at the time of the deposition. Three local pollen zones are recognized according to relative abundances of sporomorphs. The assemblage of local pollen zone ȘA-I is dominated by flooded forests and relatively low percentages of conifers and herbs. Local pollen zone ȘA-II is represented by high percentages of pines and low percentages of mixed mesophytic, swamp and riparian elements. A reduction of flooded settings is observed in the local pollen zone ȘA-III evidenced by a drop of riparian elements. The palaeoclimate predicted by coexistence analysis based on leave and palynoflora suggests that MAT ranged from 14.4 to $18.4^{\circ} \mathrm{C}, \mathrm{CMT}$ from 5.6 to $12.5^{\circ} \mathrm{C}$, WMT from 24.7 to $28.1^{\circ} \mathrm{C}$, MAP from 1003 to $1520 \mathrm{~mm}$, HMP from 124 to $227 \mathrm{~mm}$, LMP from 10 to $41 \mathrm{~mm}$ and WMP from 79 to $125 \mathrm{~mm}$. Annual precipitation estimated was higher than today. Together with the high percentages of mesothermic elements and low amounts of mega-mesothermic elements the data suggest a warm-temperate climate under the existence of evergreen and deciduous mixed forest assemblages during the Early-Middle Miocene in western Turkey.

\section{Acknowledgments}

This study was supported by a research grant from the Scientific and Technical Research Council of Turkey (TÜBİTAK Grant Code 106Y104). Special thanks go to Funda Akgün for her valuable contributions during the identification of palynomorphs. The assistance of Oğuz Mülayim and Sariye Duygu Üçbaș are appreciated who took part in the field works. I would also like to thank 
Vasilis Teodoridis and Angela Bruch for their constructive reviews. Comments and useful criticism of these people helped improving an earlier version of this manuscript considerably.

\section{References}

AкGÜN, F. \& Akyol, E. 1987. Akhisar (Çıtak) çevresi kömürlerinin palinolojik incelemesi. Türkiye Jeoloji Bülteni 30, $35-50$.

AkgÜN, F. \& Akyol, E. 1999. Palynostratigraphy of the coalbearing Neogene deposits graben in Büyük Menderes Western Anatolia. Geobios 32(3), 367-383. DOI 10.1016/S0016-6995(99)80013-8

Akgün, F., Kaya, T., Forsten, A. \& Atalay, Z. 2000. Biostratigraphic data (Mammalia and Palynology) from the Upper Miocene İncesu Formation at Düzyayla (Hafik Sivas, Central Anatolia). Turkish Journal of Earth Sciences 9, 57-67.

AKGÜN, F., KaYseri, M.S. \& AKkiraz, M.S. 2007. Paleoclimatic evolution and vegetational changes during the Late Oligocene-Miocene period in Western and Central Anatolia (Turkey). Palaeogeography, Palaeoclimatology, Palaeoecology 253, 56-90. DOI 10.1016/j.palaeo.2007.03.034

Akkiraz, M.S., AkgüN, F., Utescher, T., Wilde, V., Bruch, A.A., Mosbrugger, V. \& ÜÇBas, S.D. 2011. Palaeoflora and climate of lignite-bearing Lower-Middle Miocene sediments in Seyitömer and Tunçbilek subbasins, Kütahya Province, Northwest Turkey. Turkish Journal of Earth Sciences. DOI 10.3906/yer-1007-45

Aкyol, E. 1964. Türkiye Tersiyer kömürleri palinolojik etüdlerine dair başlangıç. Maden Tetkik ve Arama Enstitüsü Dergisi 63, 29-42.

AкYoL, E. 1968. Gelik civarındaki Sulu ve șüpheli Sulu damarlarının palinolojik korelasyonu. Türkiye Jeoloji Kurumu Bülteni 11, 30-39.

AlçiçEK, H. 2010. Stratigraphic correlation of the Neogene basins in southwestern Anatolia: Regional palaeogeographical, palaeoclimatic and tectonic implications. Palaeogeography, Palaeoclimatology, Palaeoecology 291, 297-318.

DOI 10.1016/j.palaeo.2010.03.002

BECKER-Platen, J.D. 1970. Lithostratigraphische Unterschungen im Kanozoikum Südwest Anatoliens (Türkei) - Kanozoikum und Braunkohlen der Turkei. Beihhefte zum Geologischen Jahrbuch 97, 1-244.

BENDA, L. 1971. Grundzüge einer pollenanalytischen Gliederung des türkischen Jungtertiärs (Känozoikum und Braunkohle der Türkei) 4. Beihhefte zum Geologischen Jahrbuch 113, 1-46.

Benda, L., Innocenti, F., Mazzuoli, R., Radiacati, F. \& StefFens, P. 1974. Stratigraphic and radiometric data of the Neogene in northwest Turkey (Cenozoic and Lignites in Turkey, 16). Zeitschrift der Deutschen Geologischen Gesellschaft 125, 183-193.

Benda, L. \& Meulenkamp, J.E. 1979. Biostratigraphic correlations in the Eastern Mediterranean Neogene. 5. Calibration of sporomorph associations, marine microfossils and mammal zones, marine and continental stages and the radiometric scale. Annales géologiques des Pays Helleniques (hors série) 1, 61-70.
Benda, L. \& Meulenkamp, J.E. 1990. Biostratigraphic correlations in the Eastern Mediterranean Neogene. Newsletter on Stratigraphy 23(1), 1-10.

Bozkurt, E. 1999. Menderes Massif: A review and comparison with the Cyclades, 103-111. In PaPanikolauo, D. \& Sassi, F.P. (eds) Palaeozoic Geodynamic Domains and TheirAlpidic Evolution in the Tethys. Special Publications of the Geological Society of Greece. IGCP Project No 276, Newsletter, No. 6.

Bozkurt, E. \& MitTwede, S.K. 2005. Introduction: Evolution of continental extensional tectonics of western Turkey. Geodinamica Acta 18, 153-165. DOI 10.3166/ga.18.153-165.

BozKuRt, E. \& OBERHÄNSLI, R. 2001. Menderes Massif (western Turkey): structural, metamorphic and magmatic evolution - a synthesis. International Journal of Earth Sciences 89, 679-708. DOI 10.1007/s005310000173

Bozkurt, E. \& Satir, M. 2000. The southern Menderes Massif (western Turkey): geochronology and exhumation history. Geological Journal 35, 285-296. DOI 10.1002/gj.849

Bruch, A. \& Mosbrugger, V. 2002. Palaeoclimate versus vegetation reconstruction - palynological investigations on the Oligocene sequence of the Sava Basin, Slovenia. Review of Palaeobotany and Palynology 122, 117-141. DOI 10.1016/S0034-6667(02)00106-9

BruCh, A. \& ZhiLIN, S.G. 2007. Early Miocene climate of Central Eurasia - evidence from Aquitanian floras of Kazakhstan. Palaeogeography, Palaeoclimatology, Palaeoecology 248, 32-48. DOI 10.1016/j.palaeo.2006.11.014

Collins, A.S. \& Robertson, A.H.F. 2003. Kinematic evidence for Late Mesozoic-Miocene emplacement of the Lycian Allochthon over the Western Anatolide Belt, SW Turkey. Geological Journal 38, 295-310. DOI 10.1002/gj.957

Ediger, V.S. 1990. Paleopalynology of coal-bearing Miocene sedimentary rocks associated with volcanics of the Biga Peninsula (NW Turkey) and the effect of volcanism on vegetation. Neues Jahrbuch für Geologie und Paläontologie, Abhandlungen 180, 259-277.

Ediger, V.S., Bati, Z. \& Alișan, C. 1990. Palaeopalynology and paleoecology of Calamus-like disulcate pollen grains. Review of Palaeobotany and Palynology 62, 97-105.

DOI 10.1016/0034-6667(90)90019-F

EmRe, T. \& Sözbilir, H. 1997. Field evidence for metamorphic core complex, detachment faulting and accomodation faults in the Gediz and Büyük Menderes Grabens, western Anatolia. Proceedings IESCA 1995(1), 73-94.

Emre, T., Tavlan, T., Akkiraz, M.S. \& İsintek, İ. 2011. Stratigraphy, sedimentology and palynology of the Neogene-Pleistocene(?) rocks around Akçațehir-Tire-İzmir (Küçük Menderes Graben, Western Anatolia). Turkish Journal of Earth Sciences 20, 27-56. DOI 10.3906/yer-1001-30

Erdei, B., Akgün, F. \& Lumaga, M.R.B. 2010. Pseudodioon akyoli gen. et sp. nov., an extinct member of Cycadales from the Turkish Miocene. Plant Systematics and Evolution 285(1-2), 33-49. DOI 10.1007/s00606-009-0253-x

Gemici, Y., AKyol, E. \& AKGÜN, F. 1993. Macro and micro fossil flora of the Șahinali (Aydın) Neogene Basin. Turkish Journal of Botany 17, 91-106.

Gemici, Y., Akyol, E., Akgün, F. \& Seçmen, O. 1991. Soma kömür havzası fosil makro ve mikroflorası. Maden Tetkik ve Arama Dergisi 11, 161-178. 
Gemici, Y., Yilmazer, Ç. \& Akgün, F. 1992. Macro and micro fossil flora of the Akçașțehir (Tire-İzmir) Neogene Basin. Turkish Journal of Botany 16, 383-393.

Gürer, A., Bozcu, M., Yilmaz, K. \& Yilmaz, Y. 2001. Neogene basin development around Söke-Kușadası (western Anatolia) and its bearing on tectonic development of the Aegean region. Geodinamica Acta 14, 57-69.

DOI 10.1016/S0985-3111(00)01059-7

Gürer, O.F., Sarica-Filoreau, N., Özburan, M., Sangu, E. \& DoĞAn, B. 2009. Progressive development of the Büyük Menderes Graben based on new data, western Turkey. Geological Magazine 146(5), 652-673.

DOI $10.1017 /$ S0016756809006359

GRIMM, E. 1994. TILIA and TILIAGRAPH Pollen Diagramming Program. Illinois State Museum, Springfield, IL.

Ivanov, D., Ashraf, A.R. \& Mosbrugger, V. 2007. Late Oligocene and Miocene climate and vegetation in the Eastern Paratethys area (northeast Bulgaria), based on pollen data. Palaeogeography, Palaeoclimatology, Palaeoecology 255, 342-360. DOI 10.1016/j.palaeo.2007.08.003

Ivanov, D., Ashraf, A.R., Mosbrugger, V. \& Palmarev, E. 2002. Palynological evidence for Miocene climate change in the Forecarpathian Basin (Central Paratethys, NW Bulgaria). Palaeogeography, Palaeoclimatology, Palaeoecology 178, 19-37. DOI 10.1016/S0031-0182(01)00365-0

JiMÉNEZ-MoRENo, G. 2005. Utilización del análisis polínico para la reconstrucción de la vegetación, clima y paleoaltitudes a lo largo de arco alpino europeo durante el Mioceno (21-8 m.a.). 318 pp. Ph.D. thesis, Universidad de Granada, Granada, Spain.

Jiménez-Moreno, G., Mandic, O., Harzhauser, M., Pavelić, D. \& VRanjKović, A. 2008. Vegetation and climate dynamics during the early Middle Miocene from Lake Sinj (Dinaride Lake System, SE Croatia). Review of Palaeobotany and Palynology 152, 237-245.

DOI 10.1016/j.revpalbo.2008.05.005

Jiménez-Moreno, G., Popescu, S.M., Ivanov, D. \& Suc, J.P. 2007. Neogene flora, vegetation and climate dynamics in southeastern Europe and the northeastern Mediterranean, 503-516. In Williams, M., HaYwood, A.M., Gregory, F.J. \& Schmidt, D.N. (eds) Deep-time perspectives on climate change: Marrying the signal from computer models and biological proxies. The Micropalaeontological Society, Special Publications. The Geological Society of London, London.

JimÉneZ-Moreno, G., RodrigueZ-Tovar, F.J., PARdo-IGUZquiza, E., FAuquette, S., Suc, J.-P. \& Muller, P. 2005. High-resolution palynological analysis in late early-middle Miocene core from the Pannonian Basin, Hungary: climatic changes, astronomical forcing and eustatic fluctuations in the Central Paratethys. Palaeogeography, Palaeoclimatology, Palaeoecology 216(1), 73-97. DOI 10.1016/j.palaeo.2004.10.007

KADIOĞLU, M. 2000. Regional variability of seasonal precipitation over Turkey. International Journal of Climatology 20, 1743-1760. DOI 10.1002/1097-0088(20001130)20:14<1743 ::AID-JOC584>3.0.CO;2-G

KaymaKÇı, N. 2006. Kinematic development and paleostress analysis of Denizli basin (W Turkey): implications of spatial variation of relative paleostress magnitudes and orientations. Journal of Asian Earth Sciences 27, 207-222.

DOI 10.1016/j.jseaes.2005.03.003
Kayseri, M.S. \& AKGÜn, F. 2008. Palynostratigraphic, palaeovegetational and palaeoclimatic investigations on the Miocene deposits in Central Anatolia (Çorum Region and Sivas Basin). Turkish Journal of Earth Sciences 17, 361-403.

KoçYiĞit, A. 2005. The Denizli graben-horst system and the eastern limit of western Anatolian continental extension: basin fill, structure, deformational mode, throw amount and episodic evolutionary history, SW Turkey. Geodinamica Acta 18(3-4), 167-208. DOI 10.3166/ga.18.167-208

Koralay, O.E., Dora, O.Ö., Chen, F., Satir, M. \& Candan, O. 2004. Geochemistry and geochronology of orthogneisses in the Derbent (Alașehir) Area, eastern part of the Ödemiș-Kiraz Submassif, Menderes Massif: Pan-African Magmatic Activity. Turkish Journal of Earth Sciences 13, 37-61.

Liang, M.M., Bruch, A., Collinson, M., Mosbrugger, V., Li, C.S., Sun, Q.G. \& Hilton, J. 2003. Testing the climatic estimates from different palaeobotanical methods: an example from the Middle Miocene Shanwang flora of China. Palaeogeography, Palaeoclimatology, Palaeoecology 198, 279-301. DOI 10.1016/S0031-0182(03)00471-1

MädLeR, K. \& StefFens, P. 1979. Neue Blattfloren aus dem Oligozän, Neogen und Pleistozän der Türkei. Geologisches Jahrbuch 33, 3-33.

Meulenkamp, J.E. \& Sissingh, W. 2003. Tertiary palaeogeography and tectonostratigraphic evolution of the Northern and Southern Peri-Tethys platforms and the intermediate domains of the African-Eurasian convergent plate boundary zone. Palaeogeography, Palaeoclimatology, Palaeoecology 196, 209-228. DOI 10.1016/S0031-0182(03)00319-5

Mosbrugger, V. \& Utescher, T. 1997. The coexistence approach - a method for quantitative reconstruction of Tertiary terrestrial palaeoclimate using plant fossils. Palaeogeography, Palaeoclimatology, Palaeoecology 134, 61-86. DOI 10.1016/S0031-0182(96)00154-X

NaKoman, E. 1965. Etude palynologique de quelques échantillons de lignite provenant du bassin de Thrace (Turquie). Annales de la Société Géologique du Nord 84, 298-302.

NEBERT, K. 1962. Serpantin kitleleri arasına sıkıșmıș bir Neojen blokuna misal olmak üzere Alabarda (Tavșanlı) linyit bölgesi. Maden Tetkik ve Arama Enstitüsü Dergisi 58, 31-37.

Roberts, N. \& Wright, JR. H.E. 1993. Vegetation, lake-level, and climatic history of the Near East and Southwest Asia, 194-220. In Wright, JR. H.E., KutZbach, J.E., Web III, T., Ruddiman, W.F., Street-Perrot, F.A. \& Bartlein, P.J. (eds) Global Climates Since the Last Glacial maximum. University of Minnesota Press, USA.

Robertson, A.H.F., Poisson, A. \& Akinci, O. 2003. Developments in research concerning Mesozoic-Tertiary Tethys and neotectonics in the Isparta Angle, SW Turkey. Geological Journal 38, 195-234. DOI 10.1002/gj.953

RöGL, V.F. 1998. Palaeogeographic considerations for Mediterranean and Paratethys seaways (Oligocene to Miocene). Annalen des Naturhistorischen Museums in Wien 99A, 279-310.

SeyítoĞLu, G., Ișik, V. \& ÇEmen, İ. 2004.Complete Tertiary exhumation history of the Menderes Massif, western Turkey: an alternative working hypothesis. Terra Nova 16, 358-363. DOI 10.1111/j.1365-3121.2004.00574.x 
SeyitoĞLu, G. \& Scott, B. 1991. Late Cenozoic crustal extension and basin formation in west Turkey. Geological Magazine 128, 155-166. DOI 10.1017/S0016756800018343

SeyitoğLu, G. \& Scott, B. 1992. The age of the Büyük Menderes graben (west Turkey) and its tectonic implications. Geological Magazine 129, 239-242. DOI 10.1017/S001675680000830X

Strömberg, C.A.E., Werdelin, L., Fris, E.M. \& Saraç, G. 2007. The spread of grass-dominated habitats in Turkey and surrounding areas during the Cenozoic: Phytolith evidence. Palaeogeography, Palaeoclimatology, Palaeoecology 250, 18-49. DOI 10.1016/j.palaeo.2007.02.012

SuC, J.P. 1984. Origin and evolution of the Mediterranean vegetation and climate in Europe. Nature 307(5950), 429-432. DOI 10.1038/307429a0

Suc, J.P., Bertini, A., Combourieu-Nebout, N., DiniZ, F., Leroy, S., Russo-Ermolli, E., Zheng, Z., Bessais, E. \& Ferrier, J. 1995a. Structure of West Mediterranean vegetation and climate since 5.3 Ma. Acta Zoologica Cracoviense 38, 3-16.

Suc, J.-P., Diniz, F., Leroy, S., Poumot, C., Bertini, A., Dupont, L., Clet, M., Bessais, E., Zheng, Z., Fauquette, S. \& Ferrier, J. 1995b. Zanclean ( Brunssumian) to early Piacenzian ( early-middle Reuverian) climate from $4^{\circ}$ to $54^{\circ}$ north latitude (West Africa, West Europe and West Mediterranean areas). Mededelingen Rijks Geologische Dienst 52, 43-56.

Suc, J.P. \& Drivaliari, A. 1991. Transport of bisaccate coniferous fossil pollen grains to coastal sediments: An example from the earliest Pliocene Orbria (Languedoc, southern France). Review of Palaeobotany and Palynology 70, 247-253. DOI 10.1016/0034-6667(91)90006-O

ȘENGÖR, A.M.C. 1987. Cross faults and differential stretching in their hanging walls in regions of low-angle normal faulting: examples from western Turkey, 575-589. In Coward, M.J., Dewey, J.F. \& Hancock, P.L. (eds) Continental extensional tectonics. Geological Society of London, Special Publication 28.

ȘEnGÖR, A.M.C., GÖRÜR, N. \& ȘARoĞLu, F. 1985. Strike-slip faulting and related basin formation in zones of tectonic escape: Turkey as a case study, 227-264. In BidDLE, K.T. \& CHRISTIE-Blick, N. (eds) Strike-slip deformation, basin formation and sedimentation. Society of Economic Paleontologists and Mineralogists, Special Publication 37.

Utescher, T., Duordjevic-Milutinovic, D., Bruch, A. \& MosBRUGGER, V. 2007. Palaeoclimate and vegetation change in Serbia during the last $30 \mathrm{Ma}$. Palaeogeography, Palaeoclimatology, Palaeoecology 253, 141-152. DOI 10.1016/j.palaeo.2007.03.037

ÜNAY, E. \& GökTAȘ, F. 1999. Söke çevresi (Aydın) Geç Erken Miyosen ve Kuvaterner yașlı küçük memelileri: Ön Sonuçlar. Türkiye Jeoloji Bülteni 42(2), 99-114.

Ünay, E., GÖKTAȘ, F., HaKYEMEZ, M., AvȘAR, M. \& ȘAN, O. 1995. Büyük Menderes Grabeni'nin kuzey kenarındaki çökellerin Arvicolidae (Rodentia, Mammalia) faunasina dayalı olarak yașlandırılması. Türkiye Jeoloji Bülteni 38, 63-68.

VAssilev, S.V. \& VAssiLEVA, C.G. 1996. Mineralogy of combustion wastes from coal-fired power stations. Fuel Processing Technology 47(3), 261-280.

DOI 10.1016/0378-3820(96)01016-8

YAvUZ-Ișik, N. 2007. Pollen analysis of coal-bearing Miocene sedimentary rocks from the Seyitömer Basin (Kütahya), Western Anatolia. Geobios 40, 701-708. DOI 10.1016/j.geobios.2006.11.006

YAvUZ-IșiK, N. 2008. Vegetational and climatic investigations in the Early Miocene lacustrine deposits of the Güvem Basin (Galatean Volcanic Province), NW Central Anatolia, Turkey. Review of Palaeobotany and Palynology 150, 130-139. DOI 10.1016/j.revpalbo.2008.02.001

Yilmaz, Y., Genç, Ș.C., Gürer, Ö.F., Bozcu, M., Yilmaz, K., KaraciK, Z., AltunKaynaK, Ș. \& Elmas, A. 2000. When did the western Anatolian grabens begin to develop?, 353-384. In Bozkurt, E., Winchester, J.A. \& Piper, J.D.A. (eds) Tectonics and Magmatism in Turkey and the Surrounding Area. Geological Society of London, Special Publication 173. 